Prof. dr. sc. Dubravka Hrabar

Redovita profesorica Obiteljskog prava

Pravnog fakulteta Sveučilišta u Zagrebu

\title{
POSTMODERNO DOBA KAO PREDVORJE NEGACIJE DJEČJIH PRAVA
}

$U D K: 342.7-053.2$

DOI: $10.31141 /$ zrpfs.2020.57.137.657

Izvorni znanstveni rad

Primljeno: 10. III. 2020.

\section{Djeca znače temelj društva, ona su sol zemlje. Jomo Kenyatta (1891-1978), kenijski državnik}

\begin{abstract}
Prava djece uobličena su u mnogim međunarodnim dokumentima, od kojih je najistaknutiji Konvencija o pravima djeteta. Razdoblje njezine primjene (trideset godina) dostaje za analizu njezine svrhe i sagledavanje ciljeva koji su se htjeli postići te opasnosti koje danas vrebaju da cjelokupni sustav razruše. Svijet u kojem danas žive djece u mnogim je segmentima neusporediv s vremenom kad je spomenuta Konvencija zaokružila pravni status djece. Među mnogim pravima koja bivaju ugrožena postmodernim kretanjima su djetetovo pravo na izražavanje mišljenja povezano s njegovim pravom na promjenu spola (u okviru prava na zdravlje) i pravom na identitet. Rodna ideologija posljednjih godina krči svoj put prema promjenama u društvu, ne samo u odnosu na odrasle osobe, već i na djecu, njihov odgoj i oblikovanje kroz obitelj. Nasrtaji su sve očitiji, poduprti nažalost institucijskim koracima (u Ujedinjenim narodima, Europskoj uniji i Vijeću Europe) usprkos činjenici providnosti ciljeva usmjerenih prema priznanju rodne ideologije kao nadideologije. S obzirom na vremenski odmak od donošenja Konvencije o pravima djeteta, različiti teoretičari smatraju potrebnim revidirati njezine odredbe kako bi se djecu bolje štitilo, uključujući povišenje dobne granice djetinjstva. Sukobi pogleda, jasan pogled u budućnost i dobrobit djece kao cilj, prilika su za redefiniranje svijeta i djetetovih prava, vraćajući dostojanstvo obitelji i djeci.
\end{abstract}

Ključne riječi: prava djece, pravo djeteta na izražavanje mišljenja, pravo djeteta na identitet, pravo djeteta na zdravlje, rodna ideologija.

\section{KONVENCIJA O PRAVIMA DJETETA KAO OKVIR DJELOVANJA}

Zahvaljujući donošenju Konvencije UN o pravima djeteta (1989.; u daljnjem tekstu: Konvencija) prije tri desetljeća i njezinoj gotovo univerzalnoj ratifikaciji, ${ }^{1}$ prava djece postala su predmet različitih znanstvenih i stručnih rasprava, ali i

1 Konvencija je na snazi (potpisom, pristupom, ratifikacijom ili sukcesijom) u svim državama (u Republici Hrvatskoj, Sl. list SFRJ, 15/90, NN MU, 12/90, 20/97, 4/98, 13/98), osim u Sjedinjenim Američkim Državama; usp. https://treaties.un.org/Pages/ViewDetails.aspx?src=TREATY\&mtdsg_ no=IV-11\&chapter=4\&clang=_en. U Republici Hrvatskoj objavljena je u Narodnim novinama, br. 
nezaobilazni put u promišljanjima o djeci. Konvencija o pravima djeteta predstavlja smjerokaz u povijesti dječjih prava. Već zarana iskristalizirala se ideja o tome da djeci pripadaju njihova posebna prava koja se razlikuju od prava odraslih ljudi, ${ }^{2}$ zbog specifičnosti njihova položaja, odnosno zbog njihove nezrelosti, ugroženosti i ovisnosti o odraslima. Djetinjstvo je, kao faza odrastanja, postalo zaštićeno zbog svijesti o tome da se u tome, životno relativno kratkome razdoblju, stvaraju trajne i temeljne odrednice kasnijega života, shvaćene kao pozitivni ili negativni utjecaji okoline. Odrasli ljudi djeci duguju posebnu brigu tijekom njihova razvoja kako bi ona sazrela i odrasla u cjelovite $\mathrm{i}$ ispunjene osobe, a čovječanstvo se razvijalo i opstalo. Suvremena znanost ${ }^{3}$ dovodi u nedvojbenu vezu mnoga ponašanja u odrasloj dobi s proživljenim djetinjstvom, ponekad kao odraz bolnoga odrastanja, zapuštena djetinjstva, ugrožena razvoja, ali i pozitivnog odgoja unutar obitelji. Povrh vrlo relevantnih psiholoških spoznaja o utjecaju proživljena djetinjstva na kasnija ponašanja, u pravnom segmentu valjalo je ohrabriti djecu na njihovu putu odrastanja, pa su tako djeca s kraja XX. stoljeća postala pravni subjekti, za razliku od tisućgodišnjeg statusa uzgrednoga objekta ${ }^{4}$ odnosa odraslih međusobno ili objekta u vlasništvu odraslih, najčešce njihovih roditelja i drugih zakonskih zastupnika.

No, usprkos nominalnoj podršci gotovo svih zemalja ovome važnom međunarodnom dokumentu, s njezinim ,starenjem“ razaznaju se određeni problemi koje njezini tvorci nisu mogli predvidjeti prije četrdeset godina. ${ }^{5}$ Konvencija ima mnogo svojih apologeta, no i onih koji je, u najmanju ruku, kritiziraju. Tako je pedocentrizam kao opći temelj na kojem stoji Konvencija, inspiracija pojedinim autorima da govore o pretjerivanju nazivajući ga pogrdno „,childism “. 6 Od usvajanja Konvencije postoje kritičari koji se okupljaju oko različitih okosnica njezine negacije ${ }^{7}$ uz navodni manjak ,koherentne filozofije“"8 koja bi trebala biti

2 Ideja ljudskih prava za djecu kroz njihova posebna prava opravdava se time što je postupanje $\mathrm{s}$ odraslima različito $\mathrm{u}$ odnosu na djecu, osobito $\mathrm{s}$ aspekta autonomije (prava) shvaćene $\mathrm{u}$ apsolutnim razmjerima (za odrasle) u odnosu na „rastuću autonomiju“ (za djecu). Upravo ovaj posljednji pojam predstavlja novi pojam i ravnotežu između potpune, neograničene autonomije i čovjeka/djeteta kao objekta; usp. Tobin J., Justifying Children's Rights, u: The Future of Children's Rights, Michael Freeman (ed.), Brill - Nijhoff, Leiden - Boston, 2014, str. 296.

Štoviše, presudnu važnost djetinjstva za odrasloga čovjeka primjećuju i književnici. Engleski pjesnik John Milton (1608-1674) piše: „The childhood shows the man, as morning shows the day. Be famous then by wisdom; as thy empire must extend, so let extend thy mind o'er all the world, In knowledge, all things in it comprehend. ", Paradize Regained, 4, I. 220.

4 Nepriznavanje djetetovih prava dovodilo je do infantiliziranja djece i njihova svođenja na puki objekt potrebit zaštite; usp. Tobin J., op. cit. bilj. 2, str. 296.

5 Riječ je o razdoblju od 1978. godine kad se pojavljuje prvi nacrt Konvencije, a oko čijeg je teksta usuglašavanje trajalo deset godina.

6 Slično pejorativnim pojmovima rasizam, seksizam i sl.; usp. Young-Bruehl E., Childism, New Haven, Yale University Press, 2012, prema Freeman M., Children's Rights Past, Present, and Future: Some Introductory Comments, u: The Future of Children's Rights, Michael Freeman (ed.), Brill - Nijhoff, Leiden - Boston, 2014, str. 5.

7 Riječ je o različitim znanstvenicima koji zamjeraju da Konvencija nije išla dovoljno daleko, zatim da su prava djeca katalogizirana u međunarodnom dokumentu, da postoje bolji načini zaštite djece, da djeci nedostaje sposobnost ostvarivati svoja prava, da je Konvencija anti-obiteljska i da predstavlja neokolonijalizam Zapada prema nerazvijenim zemljama; usp. Freeman, M, ibid., str. 6.

8 Freeman, M., ibid., str. 5. 
njezina misao vodilja. Bez obzira na njezine zagovornike ili protivnike, vrijeme kao neumitni sudac jest najbolji test za njezinu vrijednost. Svijet se drastično i strelovito promijenio kroz posljednjih trideset, a osobito zadnjih desetak godina, a promjene se ne prelamaju samo na leđima odraslih, već i djece koja su „materijalno zarobljena“ i kroz to objekt novog iskorištavanja. ${ }^{9}$ Djeca su sve više „materijalizirana, pretila, pod stresom, depresivna i samouništavajuća“, ${ }^{10}$ a izazovi se množe i pogađaju svu djecu. Smith, a s njime bismo se složili, govori o globalizaciji koja ima tendenciju, a mi bismo dodali i cilj, nametnuti zapadnjački model djetinjstva djeci iz zemalja u razvoju ${ }^{11}$. Jones se direktno suprotstavlja ovakvom stilu nametanja vrijednosti suprotstavljajući pojmu „globalno dijete" pojam "normalno dijete“"12! U vrijeme donošenja Konvencije o pravima djece mnogi problemi nisu postojali ili barem ne u takvom obimu, pa primjerice alkoholizam ${ }^{13}$ među djecom nije bio toliko raširen, o drogiranju djece se govorilo tek kao o prevenciji koja očito nije dala dostatne rezultate. Danas djeca žive drugačije, no nužno ne i bolje.

Međunarodni globalni i regionalni ugovori koji slijede Konvenciju o pravima djeteta ${ }^{14}$, preuzimaju u njoj zapisane standarde te izdvajaju i uređuju neka posebna prava djece ne bi li još detaljnije sankcionirali pojedina područja života djece i tako im osigurali poštovanje. Ideja postojanja prava djece prodrla je u sva nacionalna zakonodavstva na različitim razinama (kroz propise, strategije i agende) i u razna pravna područja kako bi slika prava djece i njihova zaštita bila cjelovita. Pedocentrizam je postao neprijeporni gospodar odnosa odrasli-dijete, pa su pod „,utjecaj djece i njihovih prava“" potpali svakodnevni jezik, sudovi, zakonodavstva, think-thank-ovi, tvorci javnih politika (policy-makers), znanstvenici svih disciplina ${ }^{15}$.

Konvencija o pravima djeteta uređuje mnoštvo prava djece te počiva na četiri načela, od kojih su neka ujedno i prava djece zbog svoje važnosti uzdignuta na razinu načela i utkana u samu srž i ciljeve Konvencije. U pravnoj teoriji načelo utjelovljuje hijerarhijski najviši rang ideje i predstavlja temelj za prosuđivanje

9 Tako Giroux H. \& Pollock G., The Mouse That Roared, prema Freeman, M., ibid., str. 8.

10 Tako Beder, Varney i Gosden prema Freeman M., op. cit. bilj. 6., str. 8

11 Smith R., A Universal Childhood?, London: Palgrave Macmillan, 2012., prema Freeman, M., op. cit. bilj. 6, str.11. Uz sve prednosti koje zapadno društvo ima glede, u načelu boljih uvjeta za život izvan siromaštva, istodobno ono predstavlja prijetnju za djecu zbog izjednačavanja ponašanja djece s odraslima $\mathrm{i}$ to u mnogim sferama. Tako neki autori (npr. Veerman Ph. E., The Aging of the UN Convention on the Rights of the Child, u: The Future of Children's Rights, Michael Freeman (ed.), Brill - Nijhoff, Leiden - Boston, 2014, str. 16 i d.) navode mnoštvo radnji iz elektroničkog svijeta u kojem djeca nadmašuju odrasle (npr. twitanje, sms poruke, on-line klađenje, igrice), a da se pritom ne umiju prikloniti pravome izboru, do zloporabe alkohola, cigareta, droge, pretjeranog gledanja televizije, internetskog pretraživanja $\mathrm{i}$ internetskog skidanja glazbe, video-igrica (čak u vrtićkoj dobi).

12 Gareth A. Jones kaže: „... The notion of the 'global child' as the holder of rights is a barelyobscure western-centric view of 'normal' child-adult and child-society relations that condemns 'other' styles of upbringing as 'outside' childhood", usp. prema Freeman M., op. cit. bilj. 6, str. 11.

13 Veerman Ph. E., op. cit. bilj. 11, str. 25 navodi kako Konvencija ne spominje alkohol, ali niti ulogu elektronskih komunikacijskih naprava koje mogu utjecati na zdrav razvoj djeteta.

14 Riječ je sad već o nemalom broju konvencija Vijeća Europe, ali i o trima fakultativnim protokolima uz Konvenciju o pravima djeteta. O tome usp. Hrabar D., Obiteljsko pravo u sustavu socijalne skrbi, Narodne novine, 2019., str. 12 i d.

15 Freeman M., op. cit. bilj. 6, str. 5. 
odnosno tumačenje ostalih odredaba nekog propisa te zahtjeva razradu i usklađenost kroz pojedinačne norme. Riječ je o dva prava koja su istodobno postala i načela: pravo djeteta na izražavanje mišljenja o stvarima koje ga se tiču (iz čl. 12.) i pravo djeteta na život, opstanak i razvoj (iz čl. 6) ${ }^{16}$. Preostala dva načela su načelo najboljeg interesa djeteta (iz čl. 3.) i načelo zabrane diskriminacije (iz čl. 2.). Posebna je vrijednost Konvencije o pravima djeteta što je istaknula posebnu ulogu roditelja kroz njihovo zajedništvo u odgovornosti za dijete stvarajući između samih roditelja pozitivnu napetost usmjerenu dobrobiti djeteta uz njihovu istodobnu pravnu legitimaciju prema trećim osobama (uključujući državna i druga tijela) u smislu njihove vodeće i najvažnije uloge u odgoju djeteta. Konvencija roditelje prepoznaje kao primarne odgajatelje uz zadaću usmjeravanja djeteta i njegova vođenja u ostvarivanju konvencijskih prava ${ }^{17}$.

Konvencija, kako je u mnogim odredbama često slučaj, postavlja se imperativno u odnosu na dužnost države ${ }^{18}$ da ne bude pasivna, već da pomogne kako djeci, tako i odraslima, ponajprije roditeljima, u ostvarivanju njihovih odgovornosti i dužnosti odgoja $^{19}$ djeteta. Odgoj djece međuljudski je odnos u kojem se stvaraju uvjeti za razvoj ljudske jedinke sa svrhom poticanja rasta i razvoja ličnosti ${ }^{20}$, svrhovit je, složen i dugotrajan proces, kojemu je jedno od ,važnijih obilježja prenošenje iskustava, znanja, umijeća, postignuća, običaja i shvaćanja starijih naraštaja na mlađe“"21. Odgoj djece je sredstvo rasta i preoblikovanja djeteta u rukama odraslih, a smisao je prenošenje raznolikih sadržaja na djecu ${ }^{22}$. Valja očekivati da vlastita pozitivna

16 Pravo djeteta na razvoj sadržano je u više članaka Konvencije o pravima djeteta i doživljava ga se u psiho-socijalnom kontekstu; odnosi se na tjelesni, duševni, moralni, društveni, kulturni, duhovni i osobni razvoj te razvoj talenta. Djetetov razvoj usredotočen je na transformaciju djeteta iz djetinjstva u odraslo doba. O tomu v. više: Peleg N., Reconceptualizing the Child's Right to Development: Children and the Capability Approach, u: The Future of Children's Rights, Michael Freeman (ed.), Brill - Nijhoff, Leiden - Boston, 2014, str. 386.

17 Usp. članak 5. Konvencije o pravima djeteta.

18 Primjerice u članku 18. koji govori o dužnosti države da osigura priznanje načela o zajedničkoj odgovornosti obaju roditelja za odgoj i razvoj djeteta, te da pruži odgovarajuću potporu u tome smislu.

19 Pojam upbringing/Erziehung/ élever/ allevare različito se prevodi u hrvatskome jeziku - kao podizanje, odgoj, odgajanje. Odgoj djece najuže je povezan s roditeljstvom kojemu je univerzalni cilj „osiguravanje djetetova zdravlja i preživljavanja, podučavanja vještinama za ekonomsku samostalnost te razvijanje djetetovih osobina koje se u određenom kontekstu smatraju vrlinama“, usp. LeVine R. A. i dr., Parental Behavior in Diverse Societies, New Directions for Child Development, 40. San Francisco: Jossey-Bass, prema: Pećnik N., Suvremeno roditeljstvo i prava djeteta, u: Prava djece - multidisciplinarni pristup, Dubravka Hrabar (ur.), Zagreb, 2016., str. 174.

20 O odgoju djece v. pobliže: Bognar L., Metodika odgoja, Osijek, 2001, Sveučilište J.J. Strossmayera u Osijeku.

21 „Odgoj je svrhovit, složen, i dugotrajan proces u kome se očituje jedinstvo odgojnog cilja i zadataka, načela i metoda, što u planski ostvarenom odgojnom djelovanju, uz aktivno i skladno sudjelovanje brojnih odgojnih činitelja, teži izgrađivanju potpune ljudske osobnosti/ličnosti (Vukasović, 2001). Jedno od važnijih obilježja odgoja je prenošenje iskustava, znanja, umijeća, postignuća, običaja i shvaćanja starijih naraštaja na mlađe“, Vukasović A., Etika, moral, osobnost: moralni odgoj u teoriji i praksi odgajanja, Zagreb, 1993.

22 Bognar B., Čovjek $i$ odgoj, Metodički ogledi, 22, 2, 2015, 9-37 navodi: „U znanosti o odgoju pedagogiji - postoje različite definicije temeljnog pojma odgoja. Autori se uglavnom slažu da je odgoj specifično ljudska aktivnost čovjekovog postajanja čovjekom."“ (https://doi.org/10.21464/mo42.222.937, pristup: 19.2. 2020.). 
iskustva roditelji prenose na djecu, jer je to provjereni model kojega se lako predaje djetetu i oponaša. Kad država počne nametati svoje odgojne sadržaje i standarde neminovno dolazi do konfuzije ovlasti, zbunjenosti djece i marginalizacije uloge roditelja. Osobito je to uočljivo kod vrijednosnih pitanja kao dijela svjetonazora koji roditelji žele prenijeti djetetu.

Prema Konvenciji o pravima djeteta iščitava se, s jedne strane primarna uloga roditelja u odgoju djece, a s druge strane podredna i pomažuća uloga države. Prema tome, uloga države i uloga roditelja su razgraničene. Roditelji su prije svih odgovorni za odgoj i razvoj djeteta. Oni dijete trebaju staviti ispred svega, iznad svega i u središte svega. ${ }^{23}$ Roditelji su ti koji imaju ne samo dužnosti i prava, već i odgovornost kao veći stupanj pravne vezanosti, a realizacija njihovih postupaka mora biti vođena najboljim interesom djeteta kao pravnim načelom. Kad čl. 3. ${ }^{24}$ Konvencije najbolji interes djeteta postavlja kao modus ponašanja odraslih te kao svrhu postojanja i ostvarivanja prava djece u svakom konkretnome slučaju, ispunja se svrha Konvencije naznačena u Preambuli ${ }^{25}$. Preambule konvencija uglavnom predstavljaju „korak ispred“ te sukus ciljeva i načela koji svečanom intonacijom osustavljuju cijeli tekst (međunarodnog) ugovora. Kad se promotre dijelovi Preambule Konvencije o pravima djeteta postaje razvidno da se kao načela i ciljevi postavljaju: priznanje prirodnoga dostojanstva ${ }^{26}$ djeteta, ravnopravnost,

23 Pećnik N., op. cit. bilj. 19, str. 175 upozorava na recentna istraživanja čiji rezultati govore o „ometanju“ roditeljske uloge i njihove odgovornosti spram djece zbog sve intenzivnijih zahtjeva radnog mjesta te nestalnosti zaposlenja.

24 Članak 3. obvezuje javne i privatne ustanove, pravosuđe, upravna i zakonodavna tijela na poštovanje djetetova najboljeg interesa kao primarnog interesa u svim odlukama i radnjama koje se poduzimaju. Riječ je o holističkom pristupu djetetovu razvoju koji podrazumijeva djetetov tjelesni, duševni, duhovni, moralni, psihološki i društveni razvoj (usp. Opći komentar br. 5, 2003., par. 12. Odbora za prava djeteta). Odbor za prava djeteta u Općem komentaru br. 14 iz 2013. godine očekuje primjenu ovog načela i u odnosu na odluke svih osoba povezanih s djecom, uključujući roditelje i skrbnike (par. 10.). Odbor za prava djeteta objelodanjuje različite opće komentare kojima tumači pojedina prava i načela iz Konvencije o pravima djeteta.

25 Ciljevi Konvencije o pravima djeteta sadržani u Preambuli rijetko se ističu, no jednako su važni kao i preostali dio Konvencije, pa u vezi s temom ovoga rada izdvajamo sljedeće:

„... smatrajući da je u skladu s načelima proklamiranim u Povelji Ujedinjenih naroda, priznanje prirodnog dostojanstva te jednakih i neotuđivih prava svih članova ljudske obitelji temelj slobode, pravde i mira u svijetu,

imajući na umu da su narodi u Povelji Ujedinjenih naroda ponovno potvrdili vjeru u temeljna ljudska prava, kao i u dostojanstvo i vrijednost ljudske osobe te odlučili pridonijeti društvenom napretku $\mathrm{i}$ podizanju uvjeta života u većoj slobodi, ...

svjesne činjenice da dijete, radi potpunoga i skladnog razvoja svoje osobnosti, treba rasti u obiteljskoj sredini, u ozračju sreće, ljubavi i razumijevanja,

uzimajući u obzir važnost tradicije i kulturnih vrednota svakog naroda u zaštiti i skladnom razvoju djeteta,

svjesne važnosti međunarodne suradnje za poboljšanje uvjeta života djece u svim zemljama, osobito u zemljama u razvoju, ...".

26 Tobin J., op. cit. bilj. 2, str. 297. pozivom na drugog autora (Rorty) navodi kako „Preambula Konvencije o pravima djeteta ističe inherentno dostojanstvo i neotuđiva prava svakog djeteta, ali se ne može smatrati da ovaj instrument reflektira jasnu teoriju ljudskih prava za djecu ili 'postojanje univerzalne ljudske prirode"“ (prijevod autorice), te navodi da Konvencija i njezina Preambula predstavljaju „dinamičku pojavu“" koja je odraz ,slučajnosti antropološke stvarnosti i suvremenih političkih uvjeta“ u vrijeme donošenja Konvencije. 
vrijednost ljudske osobe, nediskriminacija, važnost djetinjstva i obitelji, odgoj djece usklađen s najvišim vrjednotama, posebna skrb i pozornost za djecu i njihova zaštita, ukorijenjenost djece u nacionalne tradicije i kulturu. Pridodaju li se mislima iz Preambule pojedina prava djece zaštićena u daljnjem tekstu Konvencije, zatim već spomenuta načela (najboljeg interesa djeteta, prava na život, opstanak i razvoj, zabrane diskriminacije i prava djeteta na izražavanje mišljenja) te na kraju i uloga roditelja u odrastanju djeteta, slika postaje cjelovita. Dijete je u središtu, a cilj je odrastanje u sretnome djetinjstvu. No, je li nama odraslima dijete baš uvijek u središtu? Uspijevamo li nametnuti zdrav razum našim odlukama imajući za cilj zdravo dijete, kulturološki i individualno uklopljeno u sredinu u kojoj živi, ustežući se od udovoljavanja vlastitim ili djetetovim prohtjevima kad ona in finem ne pogoduju zahtjevu za dostojanstvom djeteta? Čini se da nekim novim tumačima Konvencije o pravima djeteta ona postaje sredstvo za vlastite probitke, a ne imperativ postavljen za zaštitu i odrastanje djece.

Turbulentna vremena u kojima živimo is kojima je teško nositi se, nameću mnoga bremena odgajanja vlastite djece. Premda je uloga roditelja potpuno jasna i ne dvoji oko njihove odgajateljske pozicije, ponekad roditelji ne djeluju za dobrobit djeteta, već se priklanjaju osobnim porivima, društvenim utjecajima i modi življenja. Velike individualne slobode slabe zajedništvo, štoviše dekonstruiraju ga i destruiraju, a često postaju svojevrsna legitimacija za ulazak u područje ljudskih prava i provedbu pojedinčeve autonomije. Jedna od većih opasnosti za opstanak obitelji, pa na kraju i društva kakvo smo do sada poznavali i uživali, jest rodna ideologija. Rodna ideologija može biti, kako će se infra vidjeti u direktnoj konfrontaciji s pravima djeteta.

\section{PRAVO DJETETA NA IZRAŽAVANJE MIŠLJENJA U SKLOPU PRAVA NA ZDRA VLJE}

Priznajući djetetu pravo da izrazi mišljenje o stvarima koje ga se tiču ${ }^{27}$ dijete je neprijeporno postalo subjektom pravnih odnosa. ${ }^{28}$ Ovo pravo djeteta odražava temeljne vrijednosti Konvencije i predmetom je analize tzv. Općeg komentara br. $12^{29}$ te ne predstavlja samo zasebno pravo, već ga valja smatrati kao sredstvo

27 Članak 12. određuje: „1. Države stranke će osigurati djetetu koje je sposobno oblikovati svoje osobno mišljenje, pravo na slobodno izražavanje svog mišljenja o svim pitanjima koja se na njega odnose, i uvažavati to mišljenje u skladu s dobi i zrelošću djeteta. 2. U tu svrhu, djetetu se napose mora osigurati da bude, izravno ili preko posrednika, odnosno odgovarajuće službe, saslušano u svakom sudskom i upravnom postupku koji se na njega odnosi na način koji je u skladu s postupovnim pravilima domaćeg prava.“

28 S pravom djeteta na izražavanje mišljenja blisko je povezano i pravo na slobodu izražavanja iz čl. 13. kojim se štite sloboda traženja, primanja i širenja informacija i ideja svake vrste, te je blisko povezano s djecom u medijskom prostoru. O tome v. više: Lisičar, H., Pravni aspekti zaštite maloljetnika u elektroničkim medijima, u: Prava djece - multidisciplinarni pristup, Dubravka Hrabar (ur.), Zagreb, 2016., str. 119-145, U ovome tekstu ne bavimo se tim dijelom djetetovih prava.

29 General Comment no. 12 (2009) The right of the child to be heard, par. 2. CRC/C/GC/12, 20. 7. 2009, https://www.refworld.org/docid/4ae562c52.html [pristup: 23. 1. 2020]. 
interpretacije i primjene svih drugih prava (par. 2 Općeg komentara). Prema Općem komentaru br. 12 ono se odnosi na pravni i društveni status djeteta (par. 1.), povezano je s drugim načelima kao što su pravo na nediskriminaciju (čl. 2.) i najbolji interes djeteta (čl. 3.), te s drugim pravima kao što su građanske slobode (osobito pravo na slobodno izražavanje, čl. 13.) i pravo na informaciju (iz čl. 17).

U praksi je riječ o participaciji djece u društvenim odnosima (par. 3). Dakako, što je dijete starije, sposobnost izričaja je jasnija, no već od najranije dobi dijete ima sposobnost artikuliranja svojih osjećaja i želja, pa upravo zato Konvencija o pravima djeteta vrjednuje srž izraženog mišljenja u skladu s djetetovom dobi i zrelošću. Osim toga, pretpostavka da bi dijete svoje mišljenje izrazilo, jest da ga je „sposobno oblikovati“. Mišljenje kao kognitivni proces oformljuje se na temelju premisa, a to su informacije iz izvanjskog svijeta koje moraju biti potpune da bismo oformili mišljenje. Zrelost, najčešće povezana s dobi, glavni je čimbenik od utjecaja na mogućnost formiranja mišljenja i potom njegova izražavanja. Oblici izražavanja razlikuju se od djeteta do djeteta, ovisno o dobi i drugim individualnim karakteristikama koje su opet produkt nasljeđa i odgoja. Kognitivna psihologija bavi se spoznajnim procesima te procesima kojima se stječe znanje i rješavaju problemi, a to su percepcija, pozornost, pamćenje, mišljenje, učenje i govor. Svi psihički procesi, od inteligencije do emocija, utječu na ponašanje čovjeka ${ }^{30}$. Kad je o djetetu riječ, posebice su važne vještine tumača djetetova mišljenja, jer odrasli su osobe koje trebaju djetetovo mišljenje prepoznati i prenijeti ga u danoj situaciji.

Zanimljiva je praksa Europskoga suda za ljudska prava koji pravo djeteta na izražavanje mišljenja ne shvaća kao apsolut, već ga vrjednuje zajedno s drugim čimbenicima ${ }^{31}$.

Izvorno Konvencija govori o djetetovim pogledima (views), no taj pojam treba shvatiti vrlo široko i obuhvatiti djetetove želje, sklonosti, stavova, namjere, ukuse, naklonosti, izbore, preferencije i na kraju mišljenje koje je verbalna ili neverbalna poruka o djetetovom unutarnjem identitetu.

Odbor za prava djeteta u svojem Općem komentaru br. 12 posvećenom pravu djeteta na izražavanje mišljenja napominje kako je riječ o pravu djeteta, dakle njegovoj ovlasti da se njime koristi, no ne i dužnosti da ga ostvaruje. Ujedno države stranke moraju osigurati ,sve potrebne informacije i savjete za dijete kako bi ono moglo donijeti odluku u skladu sa svojim najboljim interesima“" (par. 16).

30 http://www.enciklopedija.hr/Natuknica.aspx?ID=32241.

31 Riječ je o procjeni povrede čl. 8. Europske konvencije za zaštitu ljudskih prava i temeljnih sloboda, tj. o pravu na zaštitu obiteljskog života, konkretno npr. u predmetu Ribić protiv Hrvatske (zahtjev br. 27148/12, odluka od 2. travnja 2015) u kojem Sud navodi: „Pravo djeteta da izrazi svoja vlastita stajališta ne bi trebalo tumačiti na način da djeci ustvari daje bezuvjetno pravo veta, bez uzimanja u obzir drugih čimbenika i bez provođenja ispitivanja radi utvrđivanja njihovih najboljih interesa ..." (par. 143. Presude). 
Individualni pristup Konvencije svakome djetetu ponaosob ${ }^{32}$ vidljiv je ne samo iz pravno neodređenog, ali odredivog pojma ,najbolji interes djeteta“, ${ }^{33}$ već $\mathrm{i}$ iz isto tako neodređenog pojma „sposobnosti djeteta da oformi svoje mišljenje (poglede)“. Nije riječ o ograničenju, već naprotiv o predmnijevi da dijete jest sposobno oblikovati svoje mišljenje i izraziti ga (par. 20). Izražavanje mišljenja ne mora nužno biti verbalno, jer u skladu s istraživanjima i znanstvenim otkrićima dijete je sposobno oformiti svoje poglede, izbore i preferencije i u najranijoj dobi - kroz igru, govor tijela, izraz lica, crtanje i slikanje (par. 21). ${ }^{34} \mathrm{Na}$ državama, a najčešće na odraslim osobama jest da djetetove poglede prepoznaju i uvaže. Razvojne sposobnosti djece ${ }^{35}$ povećavaju se, nedvojbeno se i mijenjaju, pri čemu neke potrebe djece nestaju, a druge nastaju i rastu s dobi i olakšavaju odraslima prepoznavanje njihove nutrine, istodobno umanjujući zaštitničku ulogu roditelja ${ }^{36}$ na račun rasta autonomije djeteta.

Konvencija o pravima djeteta ima vrlo široku formulaciju u odnosu na objekt djetetova izražavanja, pa se Odbor za prava djeteta u spomenutomu Općem komentaru br. 12 referira na izražavanje mišljenja od strane djeteta u: sudskim postupcima ${ }^{37}$ obitelji, alternativnoj skrbi, zdravstvenoj problematici, obrazovanju i školovanju, igri, rekreaciji, sportskim i kulturnim aktivnostima, pri zaposlenju, u slučaju nasilja itd. Djetetove sposobnosti izražavanja mišljenja i njihov razvoj ovise o informacijama, iskustvu, okolini, društvenim i kulturološkim očekivanjima, razini podrške (par. 29.).

Budući da nam je namjera istražiti trigon odnosa prava djeteta na izražavanje mišljenja, njegova prava na zdravlje i prava na identitet, u sjeni roditeljske primarne odgovornosti za dijete, važno je kako protumačiti djetetovo pravo na zdravlje i s time povezane postupke u svrhu liječenja i ozdravljenja. Prema Općem komentaru br. 12 riječ je o djetetovom izražavanju mišljenja u pojedinačnim odlukama o

32 Tzv. case-by-case procjena (par. 29. Općeg komentara br. 12).

33 Hrabar D. definira najbolji interes djeteta kao postupanje odnosno donošenje odluke u skladu s onim što bi dijete za sebe (i o sebi) odlučilo kad bi za to bilo sposobno; usp. Hrabar D., The Legal Protection of the Best Interests of the Child, u: European Training on the Convention on the Rights of the Child, ed. Rädda Barnen/Swedish Save the Children \& Centre for Social Policy Initiative, Zagreb, 1998. str. 27.

34 O razvojnim sposobnostima djece usp. Lansdown G., The evolving capacities of the child, Innocenti Research Centre, UNICEF/Save the Children, Florence, 2005 (https://www.unicef-irc.org/publications/ pdf/evolving-eng.pdf, (pristup: 28. 1. 2020.).

35 „The concept of evolving capacities is central to the balance embodied in the Convention between recognising children as active agents in their own lives, entitled to be listened to, respected and granted increasing autonomy in the exercise of rights, while also being entitled to protection in accordance with their relative immaturity and youth. It provides the framework for ensuring an appropriate respect for children's agency without exposing them prematurely to the full responsibilities normally associated with adulthood. "usp. ibid, str. 3.

$36, \ldots$ as children's capacity evolves, parental rights gradually cede to the child and she or he is entitled to exercise those rights on her or his own behalf“, ibid., str. 5.

37 I jedan drugi važan međunarodni izvor - Konvencija Vijeća Europe o ostvarivanju djetetovih prava (1996.) poznaje u okvirima sudskih postupaka djetetovo pravo na izražavanje mišljenja u postupku ako „ima dovoljnu sposobnost razumijevanja“ (čl. 3.). 
zdravlju, kao i o uključenosti djece u razvoj zdravstvenih politika i servisa (par 98). ${ }^{38}$ Zahtjev je da se djecu uključi u proces odlučivanja o njihovu zdravlju, a u skladu s njihovim razvojnim sposobnostima. To znači da ih treba opskrbiti s potrebnim informacijama o liječničkom tretmanu i mogućim ishodima ${ }^{39}$ (par. 100.) kroz povjerljivo medicinsko savjetovanje bez roditelja, bez obzira na dob djeteta (par. 101). Ta se potreba naglašava osobito u odnosu na zdravstveni/spolni odgoj i pristup djeteta zdravstvenim uslugama, naročito kad bi postojao konflikt između djeteta i roditelja po tom pitanju. Pravo na savjetovanje i savjet odražavaju nedostatnu količinu znanja i informacija djeteta o konkretnom zdravstvenom ili medicinskom problemu u kojem se dijete zateklo, te pretpostavlja da će djetetovo mišljenje odnosno odluka (u smislu pristanka) biti rezultat upravo takvog medicinskog savjetovanja. No, postavlja se pitanje sadržaja i cilja (medicinskog) savjetovanja koji može biti skriven radi postizanja točno određene odluke u djeteta, pa je kroz to vrlo dvojbena neutralnost i objektivnost liječnika koji bi takvu informaciju i savjet dao. Dovoljno je zamisliti maloljetničku trudnoću i dvojbu maloljetnice oko pobačaja, a s druge strane pro life ili pro choice liječnika i njegovu informaciju o zdravlju maloljetnice nakon obavljena pobačaja. Vrlo je izvjesno da će odluka djeteta ovisiti o načinu kako mu je stanje predočeno. Idemo, dakle, ususret utjecaju odraslih (čak nesrodnih) osoba na djetetovu odluku stvorenu na temelju mišljenja oblikovanog ,izvana“ manipulacijama istinom.

Čini se da je Odbor za prava djeteta u svojemu Općem komentaru br. 12 zagazio u vrlo delikatno područje. Doista, bilo je teško iskazati jedinstveno gledište spram različitih situacija u vezi sa zdravljem, a u kojima se dijete može naći. Zasigurno nije istovjetna situacija u vezi sa spolnim zdravljem šesnaestogodišnje djevojke ili trogodišnjeg dječaka koji treba biti podvrgnut transplantaciji. No, Odbor za prava djeteta odobrava uvođenje u zakonodavstvo čvrste dobne granice u odnosu na djetetov pristanak na medicinski zahvat nakon savjetovanja s nezavisnim stručnjakom uz potrebu uvažavanja mišljenja mlađeg djeteta sposobnoga izraziti svoje mišljenje (par. 102.). Po našem mišljenju ovakvim je pristupom otvorena Pandorina kutija raznovrsnih problema za koje nemamo rješenje. Slijepo preuzimanje preporuka Odbora može dovesti do teških ugroza života i zdravlja djeteta. Primjerice u Hrvatskoj ${ }^{40}$ obiteljski zakonodavac za dijete starije od 16 godina traži njegov pristanak na medicinski zahvat (uz posebne odredbe o pristancima roditelja u slučaju riskantnijih zahvata, odluci suda u slučaju konflikta interesa i hitnim medicinskim postupcima za koje nije potreban ničiji pristanak). Kako postupati ako usprkos svim

38 Par. 104 Općeg komentara br. 12. Konvencija o pravima djeteta priznaje djetetovo pravo na uživanje najviše moguće razine zdravlja, pravo na ozdravljenje i oporavak (čl. 24.), posebna prava djece s teškoćama u duševnom ili tjelesnom razvoju (čl. 23.), te na periodičnu provjeru postupaka u slučaju zbrinjavanja djeteta (inter alia) zbog tjelesnog ili duševnog zdravlja (čl. 25.).

39 Ovaj zahtjev uključuje i djecu s posebnim potrebama.

40 Članak 88. Obiteljskoga zakona (Narodne novine, br. 103/2015, 98/2019) trpi određene kritike u odnosu na prosudbu o djetetovoj zrelosti glede oblikovanja vlastitog mišljenja, zatim u odnosu na voluntarizam ovlasti (,može samostalno dati pristanak ...") bez rješenja u slučaju uskrate, u odnosu na neslaganje obaju roditelja koji zastupaju dijete, te na kraju u odnosu na ishod zdravstvenog statusa djeteta koje ne daje pristanak. 
obavijestima to dijete ne želi pristati na, premda neinvazivni postupak otklanjanja melanoma, a što će kroz neko vrijeme zasigurno dovesti do smrtnog ishoda? Tko će biti za to odgovoran? Roditelji, liječnici ili zakonodavac? Dakle, imamo zakonodavstvo usklađeno s tumačenjima Odbora za prava djeteta, ali prevelik teret na leđima djeteta. Primjer je ovo prenapregnutosti djetetovih sposobnosti da bez ikakve potrebe bude izjednačeno s odraslim osobama. Postavljamo pitanje je li dijete konvencijskim odredbama, preciznije rečeno tumačenjem Odbora za prava djeteta stavljeno izvan realnosti koju čini djetinjstvo sa svim njegovim osobinama? Čini se da je odgovor potvrdan. Jesu li tumačenja Odbora za prava djeteta izvor prava? Nedvojbeno nisu. Predstavljaju li ovakvi stavovi isključenje smisla zašto su prava djece nastala? Očigledno predstavljaju. Je li djetinjstvo socijalni ili neizbježni biološki konstrukt? ${ }^{41}$ Pledirali bismo za biološko-antropološki odgovor. Daje li Odbor za prava djeteta voluntarističko i konsenzualno tumačenje djetetovih prava, bez utemeljenja u znanosti? Nedvojbeno daje.

Zaobilaženje znanosti i ciljeva Konvencije o pravima djeteta (osobito onih iz Preambule) duboko zabrinjava jer se paralelno osamostaljenju djece kroz pogrešno shvaćanje prava na izražavanje svojeg mišljenja i autonomiju djeteta, pojavljuju područja koja odražavaju rodnu ideologiju i neoliberalne pristupe čovjeku i djetetu, a korijene imaju u tzv. Comprehensive Sexuality Education (CSE) koja je ,infiltrirana u svim područjima suvremenog svijeta ... i predstavlja jedan od najvećih napada na zdravlje i nevinost djece" ${ }^{42}$ odnosno u Smjernicama za primjenu seksualnih prava mladih ljudi (Guidance document for the implementation of young people's sexual rights ${ }^{43}$ stvarajući istodobno neku novu paradigmu najboljeg interesa djeteta „kroz nametanje nekih novokomponiranih standarda dječje dobrobiti“ kako to navodi Jakovac-Lozić. ${ }^{44} \mathrm{Kad}$ je o seksualizaciji djece riječ, onda valja napomenuti da se ona događa na dva načina - kroz pornografiju i kroz druga sredstva (uživo ili online druženje, nazočenje ili slušanje o seksualnim radnjama, u medijima, zabavi, igrama, glazbi, sugestivnom oglašavanju) među kojima se, kako ističe Helen M. Alvaré, naročito podmuklim čini školski sustav u kojem se djeca zarana ili prerano ,,izlažu seksualnim sadržajima u ime njihove zaštite od spolne zloporabe, ali i u ime ohrabrenja djece da prihvate kao jednako poželjan prostor seksualnih privlačnosti i

41 Ne postoji univerzalna definicija djetinjstva. O različitim teorijama djetinjstva v. Lansdown G., op. cit. bilj. 34, str. 9 i d.

42 Usp. Jakovac-Lozić D., Nastojanja na putu „rane seksualizacije“ djece-interes djeteta ili potreba odraslih, Zbornik radova Pravnog fakulteta u Splitu, 57, 2020, 2, str. 489. Autorica, nadalje, prikazujući kritiku svjetskog udruženja Family Watch International koje se osvrću na UNESCO-ve Smjernice iz 2018. ispravno uočava potpuno liberalni pristup, bez ikakvih ograda u poduci djeci i razlučivanju sadržaja (primjerice može se iščitati sugestija kako je poželjna seksualna sloboda bez ljubavi i sl. ).

43 Jakovac-Lozić D., ibid., str. 490 i d. analizira pojedine točke Smjernica raskrinkavajući njihov seksualizirani sadržaj i rodnu obojenost. Godine 2018. Smjernice su revidirane pod nazivom International Technical Guidance on Sexuality Education, a nastale su u suradnji UNESCO, UNAIDS, UNFPA, UNICEF i WHO.

44 Ibid., str. 18. 
vlastitog identiteta s prostorom obiteljskih zajednica (istospolnih, jednoroditeljskih, itd. $)^{\text {‘. }}{ }^{45}$

\section{POSTMODERNO DRUŠTVO I PRAVA DJECE}

Postavlja se pitanje je li rodni identitet i njegova promjena dio prava djeteta na zdravlje? No, prije odgovora na ovo pitanje valja nam se suočiti s promišljanjima postmodernoga društva kojega smo dio i sučeliti ga s temeljnim vrijednostima obitelji i prava djeteta.

Postmoderno društvo u čijem se središtu nalazimo diči se „društvenim promjenama koje oblikuju nove društvene vrijednosti “ ${ }^{46}$ a društvene promjene koje se događaju posljednjih nekoliko desetljeća određuju nov smjer društvenoga razvoja. Radi dubinskog sagledavanja položaja djeteta u vrtlogu promjena postmodernoga društva valja istaknuti osnovne karakteristike tog društva.

Teoretičari društva navode da je postmoderno društvo masovno društvo u kojem se „kidaju tradicionalne ljudske veze, neposredni kontakt čovjeka s čovjekom, njegov kontakt sa prirodnom okolinom. Razaraju se prvobitne primarne zajednice i zamjenjuju sekundarnim, povremenim i anonimnim odnosima. Ove procese prati industrijalizacija života, migracije velikog obujma, povećana socijalna mobilnost i raslojavanje društva. Nastaju krupne uniformne političke, ideološke, medijske i kulturne organizacije. Kulturna publika postaje masovna, jer to omogućavaju mediji i modifikacija komunikacija koju omogućuje tehnologija, dok se mediji nalaze u rukama snažnih državnih institucija i oligopolnih organizacija koji njima manipuliraju. Na sceni je dosad neviđena koncentracija i centralizacija društvene moći, slabljenje veza između pojedinca i društvenog odlučivanja te konformizam koji taj proces potiče, a sve to radikalno restrukturira tradicionalne obiteljske odnose kao osnovne društvene ćelije. Tako ocrtan okvir predstavlja dominantni okvir za sliku suvremenog društva, kojeg pojmovno možemo nazvati; moderno, postmoderno, masovno, postmasovno, informacijsko društvo, ili drugačije, jer pojam je uvijek "misao o biti pojave"". ${ }^{47}$ Usprkos činjenici da još uvijek postoje nemale reliquiae reliquiarum tradicionalnoga poimanja društva i priželjkivanja

45 Alvaré H. M., The sexualization of children: a massive problem with insufficient solutions, u: Marriage, Children and Family, Modern challenges and Comparative Law Peerspective, Grzegorz Blicharz ed., Wydawnictwo instytutu wimiaru sprwedliwosci, Warzawa, 2019., str. 171.

46 Dulčić D., Masovni mediji i postmoderno društvo, Media, culture and public relations, 5, 2014, 1, str. 89. Autorica ističe da se u teoriji susrećemo s pojmovima postmodernost, infimacionizam, informacijsko društvo ili umreženo društvo, odmasovljeno društvo, komunistički individualizam i dr. Postmoderno doba jest povijesna epoha koja obuhvaća gotovo sva područja odnosa među ljudima (filozofiju, književnost, umjetnost i dr.), no teško joj je odrediti početak. Većina znanstvenika rani početak joj pripisuje s krajem II. Svjetskog rata, da bi kraj 20. i početak 21. stoljeća predstavljao njezin vrhunac osobito zbog novih fenomena, posebice u komunikaciji (usp. http://www.matica.hr/vijenac/373/danas-sezivot-svodi-na-igru-22198; pristup: 13. 4. 2020.). Elementi krize postmoderne i moguće renesanse starih vrijednosti vidljivi su iz dana u dan, čemu u prilog govori recentna svjetska pandemija i ponašanja koja je među državama i pojedincima proizvela.

47 Ibid., str. 92 
utočišta i smiraja u prenesenim nam vrijednostima, suvremeno se društvo uz krezovsku pomoć medijima i nevladinim udrugama, prikazuje kao neoliberalno, premda ga, među inim, karakterizira i unutarnji strah pojedinca od represije. ${ }^{48}$

Kako prepoznati i živjeti prava djeteta u ,postmodernističkoj zbrci“ koja niječe ionako otuđenoga čovjeka koji više ne traga za istinom, već se koprca u duhovnoj krizi „opijen relativizmom, individualizmom, strastima...“49, u slobodi bez odgovornosti. Postmoderni čovjek zagovara vrijednosti prolaznosti, nepostojanosti i poželjnosti, razonode iznad dužnosti, slobode iznad solidarnosti. ${ }^{50}$ Postmoderna podupire ideje ,antihumanizma (npr. u eugenici), ekscentričnosti, disimetrije umjesto nekadašnje odgovornosti, simetrije i hijerarhije. " ${ }^{51}$ Virtualni svijet, premda bez čvrstih osnova, poželjan je svijet, svijet koji nas okružuje, iracionalni svijet koji se živi. U takvome svijetu nema mjesta za istinu jer ona je izgubljena u slobodi čovjeka činiti što ga je volja. Čovjekovo, pa i djetetovo dostojanstvo koje je nekad u filozofskome poimanju izviralo iz naturalizma i metafizike, danas izvorište ima u ljudskim pravima koja čovjeka shvaćaju na redukcionistički način. Dostojanstvo je pritješnjeno postmodernim nastojanjima pokoravanja čovjeka kao sredstva za ostvarenje nekontrolirane volje za dominacijom. U sjeni postmodernoga poimanja čovjeka, antropološki pogled shvaća čovjeka na redukcionistički i materijalistički način: "čovjek više nije osoba, biće otvoreno za druge i za onostranost već je pojedinac koji bira svoju etiku, istine; čovjek je jedinstvo snage, interesa i užitka. ${ }^{\text {"52 }}$ Napuštaju se ustaljene vrijednosti u ime novih, ,izokrenutih“ vrijednosti ${ }^{53}$, poroci

48 Mausfeld R. u djelu Angst und Macht-Herrschaftstechniken der Angsterzeugung in kapitalistischen Demokratien, Westend, a. n., str. 23 govori o različitim metodama proizvodnje unutarnjeg straha koje su svojstvene kapitalističkim demokracijama. Mausfeld štoviše govori o tome da neoliberalizam ne samo da sustavno proizvodi obični strah, već i da je do savršenstva razradio profinjene psihološke tehnike kako osigurati vlastitu stabilnost kroz proizvodnju straha (str. 99). Među inim, osvrće se i na zahtjev za pravnom sigurnošću i pravnom jasnoćom kroz precizne i sadržajne pravne norme, te ukazuje na različite društvene aktivnosti koje pridonose odustajanju od formaliziranog prava (,Entformalisierung des Rechts“) što ima za posljedicu političko nesuglasje i nepredvidivost postupaka države (str. 32). Pravnoj nesigurnosti pridonosi, osim neformaliziranog prava, i tzv. „,bianco zakonitost i buduća zakonitost“ (Blanko- und Vorschusslegalität") koji kroz takve zakone naknadno određuju što je dopušteno ili zabranjeno. Autor nadalje, uviđa da je čovjek neoliberalnih društava postao roba koju se oblikuje po ideološkom uzorku (,„Dieser neoliberale Anspruch, den Menschen als Ganzes zu einer Ware zu machen und ihn marktförmig zum gestalten und damit gleichsam einen neuen Menschen zu schaffen, kommt einem totalitären Anspruch gleich. “), str. 81. Kao što Sheldon S. Wolin kaže, riječ je o tome da neoliberalne demokracije naginju invertiranom totalitarizmu; usp. Wolin, Sheldon S., Democracy incorporated: Managed democracy and the specter of inverted totalitarianism, Princeton University Press, cit. prema Mausfeld, str. 81. Da političko-ekonomski rakurs kakav daje Mausfeld ima svoje sociološko i pravno utemeljenje, vidljivo je iz infra prikazanog utjecaja rodne ideologije na prava djece.

49 Matić D., Postmodernistička zbrka ili gdje je nestao čovjek, http://www.laudato.hr/Tko-je-ovdje/ Osvrti/Filozofijom-protiv-obmana/Postmodernisticka-zbrka-ili-gdje-je-nestao-covjek.aspx (pristup: 24. 1. 2020.)

50 Ibid.

51 Ibid.

52 Koprek I., Razarajući čimbenici braka i obitelji, Bogoslovska smotra, 85, 2015., 3, str. 774.

53 Tako Gerard Francois Dumont, usp. ibid. 
postaju vrline ${ }^{54}$, a ljudska prava se svode na ,poticajan katalog potraživanja pojedinaca“ iza čega stoje samo osobni interesi, a vrijednosti postaju odraz ljudskih strasti. U ovome vrtlogu nedostaje čvrstine, pa se pronalazi pravo koje treba takve interese i formalno potvrditi katalogizirajući prava, propisujući poželjno ponašanje uvijek usmjereno k probitku pojedinca ostavljajući golem trag napuštenoga općeg dobra. Ljudska prava uistinu više nisu univerzalna, već su samo neki ukras koji gubi sadržaj, a u ime kojih se ruše sustavi.

Ono što se događa s ljudskim pravima odrazit će se i na prava djece. Suočavamo se s opasnošću poništavanja dječjih prava prenaprezanjem njihova smisla, reduciranjem sadržaja na želje odraslih (najčešće roditelja) i napuštanjem djetinjstva kao mjesta ostvarenja dječjih prava puneći ga sadržajima odraslih kojima djeca nisu dorasla.

Postmodernizam omalovažava obitelj kao temeljnu ljudsku zajednicu, najpoželjnije okružje za rast djece i kroz tisuće godina neprijepornu kariku u lancu prijenosa generacija. Obitelj karakteriziraju zajedništvo i emocije, no kad se promiču izokrenute vrijednosti i potiče individualizam - to predstavlja njezinu potpunu negaciju. Budući da su djeca srž svake obitelji, čini se da postmoderno doba ne haje za djecu, pa niti za njihova prava. Djeca prelaze iz pedocentrističke pozicije u marginalnu i utilitarističku, a prava djece postaju tek zgodan ukrasni privjesak. Jedan od razarajućih elemenata koji napada teško izvojevanu poziciju djece kao najvrjednijeg što imamo, jest rodna ideologija.

\section{RODNA IDEOLOGIJA I PRAVA DJECE}

O rodnoj ideologiji i različitim teorijama koje je propituju može se raspravljati iz različitih uglova. Pravna analiza kao i sociološki te teološki pristupi predstavljaju načine kako opravdati ili zanijekati rodnu ideologiju kao neograničenu slobodu pojedinca da „temeljem svoje volje, želje, aspiracija, pogleda i mišljenja mijenja biološke zadanosti““.55 Biomedicinske znanosti kao egzaktne znanosti koje objektivno vrjednuju pojave živoga svijeta te nisu kulturološki i vremenski uvjetovane, zahvaljujući različitim kliničkim istraživanjima ${ }^{56}$ isključuju rod kao biomedicinski pojam, a živi svijet razlikuju po binarnome principu - samo prema muškome i ženskom spolu ${ }^{57}$. Za razliku od toga, društvene znanosti mogu nametnuti određene ciljeve kroz istraživanja koja su podložna podređivanju prema tome istom

54 O promjeni poroka u vrline, osobito pohotljivosti, vlastoljublja i sebičnosti v. knjigu Friedrich Nietzsche, Tako je govorio Zaratustra. Sv. Augustin je u svojim Ispovijestima upozorava na različite ljudske opačine i zlodjela kao što su požuda tijela, požuda očiju i oholost života; usp. Augustin A., Ispovijesti, KS, 2002., str. 48.

55 Usp. Hrabar D., Istanbulska konvencija - zamke rodne ideologije, Zagreb, 2019, str. 7.

56 Ibid., str. 9, bilj. 19.

57 Dakako, iz toga su izuzeti bespolci i poremećaji spolnih funkcija kao što je, vrlo rijetki poremećaj razvoja spolova (DSD) kojeg se još naziva interseksualnim poremećajem. 
cilju, kao što i pravna norma može biti sredstvom za postizanje cilja.$^{58}$ Objektivno sagledavanje upućuje na to da ne postoji treći spol. Američko udruženje pedijatara nedvosmisleno se izjasnilo o štetnosti rodne ideologije za djecu, ne samo u smislu njezine psihološke aplikacije na djecu, već i zdravstvenih problema koje ona sa sobom nosi. ${ }^{59}$ Stručnjaci ukazuju na mentalni poremećaj u osobe koja vjeruje da jest ono što nije, odnosno da nije iako jest i kad se to odnosi na spol ${ }^{60}$.

Rodna ideologija kao noviji društveni pogled ${ }^{61}$, pomoć u probijanju k cilju poništavanja spola kao razlike, koristi načelo zabrane diskriminacije, premda najvažniji dokumenti o ljudskim pravima ${ }^{62}$ govore o zabrani diskriminacije, inter alia, na temelju spola, a ne roda, a noviji tek gdjegdje i spolne orijentacije. Uvriježen je pojam spol (sex), a ne rod (gender) čime se željelo istaknuti jednakost u pravima žena i muškaraca. Konvencija o pravima djeteta u čl. 2. jamči primjenu prava na svu djecu bez obzira na različite karakteristike, uključujući i spol, no ne i rod. ${ }^{63} \mathrm{Bez}$ obzira što mi mislili o rodnoj ideologiji kad je riječ o odraslim osobama, pa čak i kad se znanstvene činjenice proglašavaju nekorektnima, smatramo da djecu treba u potpunosti izostaviti iz ove nove ,agende“. Na to nas pozivaju svi međunarodni dokumenti, ako ne i zdrav razum, jer djeca nisu sredstvo za ostvarenje ciljeva odraslih. Nisu, i ne smiju to biti.

Kad Ujedinjeni narodi, osobito kroz prava žena ${ }^{64}$ promiču strategiju rodne jednakosti oni eksplicite zagovaraju „rodno osviještenu politiku“ koja ne zaobilazi djecu, jer rodna jednakost kao cilj mora biti u središtu svih aktivnosti - razvojnih politika, istraživanja, zalaganja i dijaloga, zakonodavstva, financijskih sredstava i planiranja, primjene i nadzora programa i projekata. ${ }^{65}$ Rodno osviještena politika gurnula je bez ikakve dvojbe najbolji interes djeteta na marginu. Povrh toga, Ujedinjeni narodi stvaraju posvemašnju zbrku upućivanja jednog na drugo,

58 Dovoljno je podsjetiti na pravnu prošlost u nacističkim i komunističkim režimima gdje su zakoni krojili sudbine ljudi i prirodu ljudskih odnosa.

59 Jakovac-Lozić D., op. cit. bilj. 42, str. 485 i d. detaljno prenosi svih osam točaka s kojima u svojem mišljenju (revidirano 2017. godine) Američko udruženje pedijatara znanstveno oponira rodnoj ideologiji, navodeći kako: „The American College of Pediatricians urges healthcare professionals, educators and legislators to reject all policies that condition children to accept as normal a life of chemical and surgical impersonation of the opposite sex. Facts - not ideology - determine reality.", usp. str. 9. te https://www. acpeds.org/the-college-speaks/position-statements/gender-ideology-harms-children (pristup: 3. 2. 2020.)

60 Usp. Jakovac-Lozić D., ibid., str. 485 koja citira Američko udruženje pedijatara.

61 Jakovac-Lozić D., ibid. na str. 497 upućuje na Marguerite A. Peeters i njezinu knjigu Rodna revolucija - Vodič za razlučivanje, Verbum, Split, 2016. koja govori o "globalnoj političkoj normi“" i o „kulturi koja postaje globalna“.

62 Tako čl. 2. Opće deklaracije o pravima čovjeka, čl. 2. Međunarodnog pakta o građanskim i političkim pravima, čl. 14. Europske konvencije za zaštitu ljudskih prava i temeljnih sloboda, čl. 1. st. 1 . 1. Protokola navedenoj Konvenciji, čl. 21. Povelje Europske unije o temeljnim pravima, itd.

63 Riječ je o zabrani diskriminacije prema djetetu i njegovim roditeljima odnosno zakonskim zastupnicima, po osnovi rase, boje kože, spola, jezika, vjere, političkog ili drugog uvjerenja, nacionalnog, etničkog ili socijalnog podrijetla, imovine, teškoća u razvoju, obiteljskog podrijetla ili neke druge okolnosti.

64 Mislimo na tijelo Ujedinjenih naroda pod nazivom United Nations Entity for Gender Equality and the Empowerment of Women.

65 Usp. Hrabar D., op. cit. bilj. 55, str. 18, bilj. 58. 
bez čvrstih oslonaca koji bi bili jasni i prepoznatljivi, zamućujući pogled i obzor obojen duginim bojama. ${ }^{66}$ Dominantna su dva pola: holizam koji uništava tradicionalni antropocentrizam i nova ljudska prava koja proizlaze iz ,konsenzusa individualističke aritmetike probitaka i užitaka“" ${ }^{67}$ No, Ujedinjeni narodi agendu rodne ideologije suptilno nameću kroz različite djelatnosti UNICEF-a okupljene oko promicanja rodne ideologije. Riječ je o UNICEF Gender Action Plan, 20182021, o Međunarodnom danu djevojčica (International Day of the Girl Child) ${ }^{68}$ i sličnome. Dakako, djeca trebaju poslužiti za kockice nekog novog mozaičkog svijeta gdje će spol izumrijeti, a da bi se to postiglo djecu treba ,zarana tretira[ti] kao odrasle osobe, uvjerava[ti] ih da su dovoljno zreli da participiraju u svih društvenohedonističkim podvalama ..." 69

Na razini Europske unije rodna ideologija (kroz pojam gender) ne postoji. Naime, Povelja Europske unije o temeljnim pravima Europske unije (2016/C 202/02) temelji se na ,nedjeljivim, univerzalnim vrijednostima ljudskog dostojanstva, slobode, jednakosti i solidarnosti“" (iz Preambule). Nedvojbeno izostanak spominjanja istinskih kršćanskih vrijednosti na kojima počiva Europska unija od svojih početaka, nije slučajan. Lisabonski je ugovor imao čvrstu nakanu odmaknuti se od tih vrijednosti kako bi mogao djelovati erga omnes u okvirima Europske unije po zapovijedima homoseksualnih, pedofilskih i masonskih lobija.

Povelja spominje zabranu diskriminacije temeljem, inter alia, spola i spolne orijentacije, ali ne i rodne pripadnosti ${ }^{70}$. Nadalje, pojedine odredbe Povelje govore o nepovredivosti, poštovanju i zaštiti ljudskog dostojanstva (čl. 1.), o pravu na poštovanje tjelesne i duhovne cjelovitosti (čl. 3.), o pravu na slobodu i sigurnost (čl. 6.), o pravu na poštovanje privatnog i obiteljskog života (čl. 7.), o pravu na slobodu mišljenja, savjesti i vjeroispovijedi ${ }^{71}$ (čl. 10.). Stoviše sloboda vjeroispovijedi kao dio trolista sličnih i nerijetko povezanih prava, podrazumijeva i slobodu iskazivanja vjeroispovijedi kroz poučavanje i običaje (te obrede). Povelja jamči i pravo slobode izražavanja koje uključuje slobodu mišljenja (čl. 11.), a u okviru prava na obrazovanje jamči se ,pravo roditelja da svojoj djeci osiguraju obrazovanje i poduku u skladu sa svojim vjerskim, filozofskim i pedagoškim uvjerenjima..." (čl. 14.). Europska unija ,, poštuje kulturnu, vjersku i jezičnu raznolikost“ (čl. 22.). Prava djece (iz čl. 24.) sužena su na svega nekoliko ${ }^{72}$ na prostoru Europske unije najugroženijih

66 Jakovac-Lozić D., op. cit. bilj. 42 u bilj. 13, str. 484 navodi da je riječ o ,halucinantnoj holističkoj svaštarnici“ gdje svaka tema upućuje na drugu kao u igri zrcala, da bi ispalo da se vrtimo u krugu.

67 Schooyans M. Skriveno lice UN-a-Prema novoj svjetskoj vladi, Verbum, Split, 2006., str. 10-13; cit. prema Jakovac-Lozić D., op. cit. bilj. 42, str. 484, bilj. 13.

68 Usp. Jakovac-Lozić D., op. cit. bilj. 42, str. 487. U bilj. 25. autorica navodi riječi tadašnjeg glavnog tajnika Ban Ki-moona koji, usudili bismo se kazati ne razumijevajući ili namjerno izvrćući pojmove jednakosti i rodne ideologije, govori o potrebi sprječavanja diskriminacije prema djeci zbog spolne orijentacije i rodnog identiteta.

69 Jakovac-Lozić D., op. cit. bilj. 42, str. 491.

70 Čl. 21. Povelje Europske unije o temeljnim pravima.

71 I s njime povezanog prava na priziv savjesti.

72 Riječ je o pravu na zaštitu i brigu, pravu na slobodno izražavanje mišljenja i pravu na održavanje redovitih osobnih odnosa s oba roditelja. 
prava, no ističu se kriterij i načelo djetetove dobrobiti i zaštita interesa djeteta kao primarni cilj. Kulturna raznolikost djece zaštićena Poveljom ne završava s kulturom shvaćenom ${ }^{73}$ u etnografskom smislu, već mora u najširem smislu podrazumijevati znanje, vjeru, umjetnost, moral, zakone i običaj. ${ }^{74}$

Ovim europskim promišljanjima valja pridodati i ona Vijeća Europe. Riječ je o nekoliko temeljnih dokumenata koji ocrtavaju Vijeće Europe kao političku instituciju. Statut Vijeća Europe poziva se na ,ideale i načela koji su zajednička baština europskih država, odnosno na nepokolebljivu privrženost duhovnim i moralnim vrijednostima“" ${ }^{75}$ Konvencija za zaštitu ljudskih prava i temeljnih sloboda zabranjuje diskriminaciju temeljem, inter alia, spola (čl. 14.), ali ne i rodne pripadnosti. Čl. 2. Prvog protokola Europskoj konvenciji jamči roditeljima pravo da „osiguraju odgoj i poučavanje u skladu sa svojim vjerskim i filozofskim uvjerenjima" ${ }^{\text {"7 }}$.

Dakle, iz temeljnih dokumenata koji su ,,ugaoni kamen“"za iščitavanje europskoga identiteta jasno proizlazi da rodna ideologija nije u temeljima europske misli te da se ne može ,podvrstati pod ideal i načelo, zajedničku baštinu te duhovnu i moralnu vrijednost Vijeća Europe "77 ni Europske unije.

No, noviji soft-law dokumenti, bez istinskog pravnog uporišta, zaokrenuli su smjer: Strategija Vijeća Europe za prava djece (2016-2021. $)^{78}$ spominje rodnu pripadnost u vezi s mjerama protiv diskriminacije na temelju, inter alia, rodne

73 Cvjetko Milanja, Opisi $i$ definicija kulture, https://www.pilar.hr/wp-content/images/stories/ dokumenti/studije/16/milanja_kk_011.pdf (pristup: 17. 2. 2020.), str. 17 navodi:

„, Na razini „općosti“, dakle, kultura se dakako može definirati kao skup vrijednosti, običaja, vjerovanja i praksi koje sačinjavaju život neke određene skupine, a ta definicija nije od jučer. Primjerice E. B. Tylor je još 1871. definirao kulturu kao složenu cjelinu koja obuhvaća znanje, vjerovanje, umjetnost, moral, pravo, običaje, navade i ine sposobnosti koje je čovjek stekao kao član društva.". Nadalje, na str. 26. navodi: „Ipak se, u najširem smislu, može kultura motriti u skladu s UNESCO-vom deklaracijom (iz 2001.) koja sugerira kako kulturu valja promatrati kao skup distinktivnih, duhovnih i materijalnih, intelektualnih i afektivnih značajki koje karakteriziraju neko društvo. Ona, pored umjetnosti i književnosti, obuhvaća načine života, oblike života u zajednici, sustave vrijednosti, tradicije i vjerovanja.“

74 Prema definiciji kulture E. B. Tylora; usp. Hrvatska enciklopedija LZ Miroslav Krleža, natuknica kultura, Zagreb, a. n., sv. 6, str. 338.

75 Čl. 1. t. a) i Preambula Statuta, st. 1., 3. i 4. ; usp. Omejec, J. Konvencija za zaštitu ljudskih prava i temeljnih sloboda u praksi Europskog suda za ljudska prava, Strasbourški acquis, Zagreb, Novi informator, 2014, str. 3.

76 O prijeporima glede ostvarenja ovih roditeljskih prava v. Hrabar, D. Odjek roditeljskih vjerskih i filozofskih uvjerenja na odgoj i obrazovanje djece u hrvatskoj legislativi, Zbornik Pravnog fakulteta u Zagrebu, 68, 2018, 3-4, 319-336.

77 Op. cit. bilj. 55, str. 19 i d.

78 Council of Europe Strategy for the Rights of the Child, https://rm.coe.int/168066cff8. (pristup: 17. 3. 2020.). 
pripadnosti djece. ${ }^{79}$ Pojavljuju se i rezolucije koje se bave transseksualizmom ${ }^{80} \mathrm{u}$ kojima su obuhvaćena i djeca, pa se postavlja pitanje je li to situacija odnosno problem koji postoji oduvijek, je li to pojava koja je nenadano (i zašto?) narasla ili je riječ o podupiranju i promidžbi takvog stanja? Skloni smo prikloniti se tvrdnji kako ,... djecu, pored ovakvih odraslih, čeka nezavidna budućnost“"81 kad je kroje nacionalni propisi obličja ,isfabricirane kreature“ .82

No, 2014. godine pojavio se jedan nov dokument Vijeća Europe - Konvencija Vijeća Europe o sprečavanju i borbi protiv nasilja nad ženama i nasilja u obitelji ${ }^{83}$ tzv. Istanbulska konvencija, u kojem se po prvi puta spominje pojam gender. Iako je konvencija izvorno namijenjena borbi protiv nasilja nad ženama i obiteljskog nasilja, ona predstavlja opasan presedan nametanja rodne ideologije u nacionalne sustave, zbog obveze prilagodbe nacionalnog prava njezinim zahtjevima. Koliko god bilo potrebno i opravdano boriti se protiv nasilja nad ženama i u obitelji, toliko je potrebno govoriti i sprječavati i svaki drugi oblik međuljudskog nasilja - onoga prema djeci, između djece međusobno, prema muškarcima, između muškaraca i prema starijim osobama. Naš je dojam da je donošenje ove Konvencije bilo itekako potaknuto od strane različitih lobija radi preuzimanja rodne ideologije u europske dokumente. ${ }^{84}$ Sve manjkavosti Konvencije bilo bi moguće nadrasti kad bismo imali vjerodostojan odgovor na pitanje: zašto je trebalo nasilje povezivati s rodnim pristupom i zalaziti u područja koja s nasiljem nemaju nikakve poveznice, kao što su područje obrazovanja ${ }^{85}$ djece te tradicije, kulture i običaja?

Uz mnoštvo prigovora koji se ovoj Konvenciji mogu uputiti, za ovu je temu važno kratko se osvrnuti na njezin čl. 14. koji obvezuje države da u okviru obrazovanja u svoje redovite nastavne planove i programe uvedu pouku o rodnoj ideologiji kako bi se na svim razinama obrazovanja poduzelo sve u vezi s pitanjima (i) ,... nestereotipne rodne uloge, ... rodno utemeljeno[g] nasilja nad ženama ...", ne samo u obrazovnom sustavu, već i u „neformalnim obrazovnim okruženjima, sportskim i kulturnim okruženjima i okruženjima za slobodno vrijeme te u medijima“. Dakle,

79 Zanimljivo je da ova Strategija navodi u toč. 36. sljedeće „Based on Recommendation CM/ Rec(2010)5 on measures to combat discrimination on grounds of sexual orientation or gender identity, the Council of Europe will undertake research on the situation of LGBT and intersex children as regards the realisation of their rights.", a u toč. 35. osvrće se na borbu protiv (i) pretjerane seksualizacije („,oversexualisation“). Dijana Jakovac-Lozić, op. cit. bilj. 42 na str. 503 dobro primjećuje da je riječ o nametanju ,iščašenog pogleda na čovjeka“ i dvoji o tome što znači ,pretjerano“. Dodali bismo da valja zaključiti kako je seksualizacija djece prihvatljiva do neke mjere (,pretjeranosti“), ali je pitanje tko odlučuje o toj granici. Vjerojatno Vijeće Europe?!

80 Tako Rezolucija 1952(2013.) i PACE Rezolucija (2048/2015), zatim Smjernice Odbora ministara VE o djetetu prijateljskoj zdravstvenoj skrbi (2011.); usp. Jakovac-Lozić D., op. cit. bilj. 24, str. 35 i d.

81 Jakovac-Lozić D., op. cit. bilj. 42, str. 506

82 Jakovac-Lozić D., op. cit. bilj. 42, str. 510.

83 Narodne novine, MU, br. 3/2018. Do sada ju je ratificiralo 34, potpisalo 45 od 47 članica VE, uz rezerve 22 država članica (usp. https://www.coe.int/en/web/conventions/full-list/-/conventions/ treaty/210/signatures?p_auth=KxlAu3ne. - pristup: 18. 2. 2020.)

${ }_{84}$ Usp. Hrabar D., op. cit. bilj. 55, str. 34.

85 Jedno bi bilo i pritom poželjno, obvezati nacionalne sustave da u okvirima obrazovnih programa progovore o neprihvatljivosti nasilja općenito, a osobito među djecom (s obzirom na učeničku populaciju), a drugo je, što se i dogodilo, govoriti o rodno utemeljenom nasilju. 
rodna osjetljivost mora postojati u školi, izvan škole, u kulturi, u dječjoj igraonici, u sportskim udrugama i terenima, u medijima, ${ }^{86} \mathrm{u}$ knjižnicama. Da je tome tako, da se ciljevi o rodnoj ideologiji uvlače u europsko društvo, vidljivo je iz napisa o kreiranju novog kurikula odgoja u Ujedinjenoj kraljevini ${ }^{87}$. Ako je vjerovati medijima, onda je riječ o potmulom fait accomplie, o ,smrtonosnom udarcu“ u kojem nema mjesta roditeljskom odgoju, vjerskim i drugim uvjerenjima i pravu na izražavanje mišljenja.

Odredba čl. 14. Istanbulske konvencije u direktnoj je suprotnosti sa slobodom odgoja i obrazovanja djece u skladu s roditeljskim uvjerenjima zajamčenom nekolicinom ranije spomenutih međunarodnih ugovora: Opće deklaracije o ljudskim pravima UN-a ${ }^{88}$ Prvog Protokola Europskoj konvenciji za zaštitu ljudskih prava i temeljnih sloboda ${ }^{89}$ te Povelje Europske unije o temeljnim pravima. ${ }^{90} \mathrm{Ne}$ manje važan je i izričaj Rezolucije 1904 (2012) Parlamentarne skupštine VE koja govori o slobodi izbora obrazovanja u Europi. ${ }^{91}$

Članak 14. Istanbulske konvencije za države stranke stvara obvezu ${ }^{92}$ diseminacije nastavnih materijala inter alia o ,nestereotipnim rodnim ulogama“ i ,rodno utemeljenom nasilju nad ženama“ što je u direktnoj suprotnosti s pravima roditeljima

86 Op. cit. bilj. 55, str. 37.

87 Prema izvještaju Sunday Timesa akademska zajednica Oxforda suprotstavila se tzv. Stonewall grupi koja promiče rodnu ideologiju na sveučilištu (usp. https://www.dailymail.co.uk/news/article-7146961/ Leading-Oxford-academics-blast-LGBT-charity-Stonewalls-trans-awareness-training.html). Nadalje, isti medij izvješćuje o tzv. RSE - Relationships and sex education kao smjernicama za obrazovanje djece u kojima će se uključiti obvezne lekcije o "gay i trans osobama" za osnovnoškolsku djecu u dobi od četiri godine. Nacrt smjernica kaže: "Škole su slobodne same odrediti kako će se odnositi prema sadržaju koji je specifičan za LGBT populaciju, ali Odjel preporučuje da takav sadržaj bude sastavni dio nastavnog programa."; usp. https://narod.hr/eu/prema-smjernicama-lgbt-aktivista-britanske-skole-morat-ce-u-svepredmete-ugraditi-homoseksualne-i-transrodne-osobe-i-teme.

88 “...3. Roditelji imaju pravo prvenstva u izboru obrazovanja za svoju djecu.” (čl. 26.).

89 „Nitko ne može biti lišen prava na obrazovanje. U ostvarivanju svih svojih funkcija u oblasti obrazovanja i nastave država poštuje pravo roditelja da osiguraju takvo obrazovanje i nastavu koji su u skladu s njihovim vlastitim vjerskim i filozofskim uvjerenjima. “ (čl. 2.)

90 „Sloboda osnivanja obrazovnih ustanova, uz poštovanje demokratskih načela, te pravo roditelja da svojoj djeci osiguraju obrazovanje i poduku u skladu sa svojim vjerskim, filozofskim_i pedagoškim uvjerenjima, poštuje se u skladu s nacionalnim zakonima koji uređuju ostvarivanje takve slobode $i$ prava." (čl. 14.)

$91 \mathrm{U}$ toč. 2. navodi se: „It is on the basis of the right to education as explained above that the right to freedom of choice in education should be understood. This right, which is intimately linked to freedom of conscience, is enshrined in Article 2 of the Protocol to the Convention for the Protection of Human Rights and Fundamental Freedoms (ETS No. 9). It carries with it the obligation for all Council of Europe member States, in the exercise of their functions in the field of education and teaching, to "respect the right of parents to ensure such education and teaching in conformity with their own religious and philosophical convictions", in so far as these are compatible with the fundamental values of the Council of Europe. " usp. http://assembly.coe.int/nw/xml/XRef/Xref-XML2HTML-en.asp?fileid=19162.

92 Čl. 14.: „, 1. Stranke će poduzeti, kada je to primjereno, potrebne korake kako bi nastavne materijale o pitanjima kao što su ravnopravnost žena i muškaraca, nestereotipne rodne uloge, uzajamno poštovanje, nenasilno rješavanje sukoba u osobnim odnosima, rodno utemeljeno nasilje nad ženama i pravo na osobni integritet, prilagođeno razvojnim sposobnostima učenika, uključile u redovni nastavni plan i program $i$ na svim razinama obrazovanja.

2. Stranke će poduzeti potrebne korake za promicanje načela iz stavka 1. kako u neformalnim obrazovnim okruženjima, tako i u sportskim te kulturnim okruženjima i okruženjima za slobodno vrijeme te u medijima." 
u obrazovnom procesu. Naime, ,nestereotipne rodne uloge“ $\mathrm{i}$,,rodno utemeljena“ ponašanja predstavljaju sukus rodne ideologije, a svaka se ideologija, pa tako i ona rodna može kositi s filozofskim uvjerenjima roditelja koji, u ovome slučaju mogu inzistirati na pouci djece o spolnim razlikama bez rodnih „stereotipa“. Pitanje je u kolikoj mjeri roditelji smiju od obrazovnog sustava zahtijevati pouku djece usklađenu s njihovim uvjerenjima? Izvan sumnje, riječ je o nastavnim predmetima i sadržajima u kojima se dira u etička načela. No, valja imati na umu da pravo izbora nije apsolutno pravo, ${ }^{93}$ pa je roditeljskom pravu izbora obrazovanja za dijete nadređen isključivo najbolji interes djeteta. Stoga roditeljsko pravo izbora traje sve dok nije ugrožen najbolji interes djeteta koji je jedno od načela postupanja s djecom prema čl. 3. Konvencije o pravima djeteta. Skloni smo promišljanju da je intencija čl. 14. bila potajice minimalizirati roditeljski odgoj i djecu podvrgnuti novim društvenim htjenjima slično vremenima totalitarizama kad su postojale smjernice ideologiziranog društveno-politički prihvatljivog odgoja. ${ }^{94}$

Čini se da imamo konfuznu situaciju - nekoliko odredaba različitih ranijih međunarodnih i regionalnih dokumenta o roditeljskom odgojno-obrazovnom prvenstvu te novije odredbe čl. 14. Istanbulske konvencije (utjecaj rodne ideologije na nastavni plan i program $\mathrm{u}$ formalnom i neformalnom obrazovnom okruženju) te njezine eksplicitne odredbe (iz čl. 71.) kojom se isključuje utjecaj Istanbulske Konvencije na druge međunarodne instrumente. ${ }^{95}$ Mišljenja smo da prethodno spomenuti međunarodni ugovori koji uređuju pitanje odgoja i obrazovanja, imaju prednost pred odredbom čl. 14. Istanbulske konvencije, jer je njezina svrha (čl. 1.) i primjena (čl. 2.) fokusirana na borbu protiv svih oblika nasilja nad ženama i u obitelji. Hoće li u konkretnim situacijama prevladati zdrav razum i utjecanje prirodnome ili pak gender aktivizam, valja pričekati.

U tom razdoblju ,čekanja“ pojavljuje se najnoviji dokumenti - Rezolucija Europskog parlamenta o modernizaciji sustava obrazovanja u EU (2017/2224(INI)) koja uvodi rodnu perspektivu kao kriterij koji treba uvažiti u obrazovnom sustavu. ${ }^{96}$ Čudi kako jedna takva rezolucija, premda neobvezujućeg karaktera, postaje „skretničar politika“ i važnija od međunarodnih ugovora koji eksplicite priznaju roditeljska uvjerenja kao nezaobilazni čimbenik u odabiru obrazovanja njihove djece.

93 Jakovac-Lozić D., „Rod“ protiv „,spola“ - polazište na putu razaranja braka i obitelji, Zbornik radova Pravnog fakulteta u Mostaru, Petnaesto međunarodno savjetovanje „Aktualnosti građanskog i trgovačkog zakonodavstva i pravne prakse“, 2017., na str. 135. navodi: „Dovoljno je htijenje, želja pojedinca da bude ono što hoće i kad hoće, a sve pod parolama prava na izbor, jednakost, nediskriminaciju.“.

94 Ilustrativan je primjer jedne odredbe iz onodobnog hrvatskog zakona koji je uređivao obiteljske odnose. Tako je Odlukom Ustavnoga suda ukinuti čl. 70. Zakona o braku i porodičnim odnosima (NN, 11/78) glasio: „,Roditelji imaju dužnost i pravo odgajati svoju maloljetnu djecu u duhu odanosti prema socijalističkoj domovini, razvijati kod djece radne navike te ih pripremiti za samostalan život $i$ aktivne članove socijalističke samoupravne zajednice. “

$95 \mathrm{O}$ tom sukobu v. više, Hrabar D., op. cit. bilj. 55, str. $40 \mathrm{i}$ d.

96 U toč. 32. navodi se: , ... potvrđuje da je na svim razinama obrazovnih sustava potrebno voditi računa o rodnoj perspektivi kojom se u obzir uzimaju potrebe osoba koje su žrtve višestrukih oblika diskriminacije, uključujući osobe s invaliditetom, pripadnike LGBTI zajednice i osobe iz marginaliziranih zajednica;" http://www.europarl.europa.eu/doceo/document/A-8-2018-0173_HR.html. 
Daljnje pitanje vezano uz djecu i rodnu ideologiju odnosi se na razna medijska izvješća ${ }^{97}$ o promjeni spola u djece, ${ }^{98}$ koja mahom sva afirmiraju nove eksperimente s djecom. To i ne čudi s obzirom na to u čijem su vlasništvu većina medija. Zabrinjavajuće stanje implicira dva pitanja: treba li u ovome slučaju djetetovo pravo na izražavanje mišljenja i želju da promijeni spol bespogovorno uvažati kroz njegov pristanak na medicinski zahvat, a kao drugo može li se i kako opravdati najbolji interes djeteta za takvim zahvatom. Stručnjaci ističu kako je poticanje djece na promjenu spola istovjetno zlostavljanju djece..$^{99}$

Postavlja se pitanje je li pravo djeteta na identitet ugroženo ovakvim postupcima? Konvencija o pravima djeteta u odredbi čl. 7. govori o njegovu pravu na identitet kroz poznate elemente: pravo na ime ( $\mathrm{tj}$. upis u državne matice po rođenju), pravo na stjecanje državljanstva i pravo znati tko su mu roditelji. Odredba čl. 8. Konvencije obvezuje države na poštovanje djetetova prava na očuvanje svojega identiteta (,uključujući nacionalnost, ime i obiteljske odnose“), a predstavlja pravni temelj za obveze država da preveniraju nestanak djece, osobito u slučaju politički opresivnih situacija. ${ }^{100}$ Promjena spola djeteta predstavlja promjenu izvornoga, rođenoga identiteta i nedvojbeno može značiti, u okvirima rodnih ideologija, kršenje njegova prava na identitet.

Promjena spola medicinski je vrlo zahtjevan postupak ne samo zbog kirurškog zahvata, već i zbog hormonalnih posljedica na organizam te psihološke prilagodbe novome spolu. Tehničke mogućnosti medicinskih zahvata i postignuća ${ }^{101}$ zaobilaze etičke i pravne standarde dopustivog. Čini se kao da rodna ideologija i njezina

97 Tako Daily Mail izvješćuje o kalifornijskom slučaju roditelja koji su oboje svoje djece podvrgnuli promjeni spola (u suprotan spol od onog u kojem su rođeni, dječaka u djevojčicu i djevojčicu u dječaka) usp. Parents reveal both of their children are transgender after they decided to transition aged five and seven and insist they're happier than ever, https://www.dailymail.co.uk/femail/article-7296803/Parents-revealchildren-transgender.html?ns_mchannel=rss\&ico=taboola_feed\&fbclid=IwAR1DBGVX-k8ZowzjHqknsDv-ccXclALPVX81jv3glUEIDGFhL34bRuaVLA. Drugi je slučaj promjene spola četverogodišnjeg djeteta u Australiji zbog toga što vjeruje „,da je u pogrešnom tijelu“ usp. https://www.novizivot.net/4godisnje-dijete-trazi-promjenu-spola-roditelji-pristaju/ ili slučaj roditelja koji ne obznanjuju spol svojeg djeteta da bi ga odgajali „,rodno neutralno“ usp. https://www.24sata.hr/fun/roditelji-vec-dvije-godinene-zele-otkriti-spol-djeteta-123240. Daljnji je slučaj majke koja je izgubila spor pred sudom htijući svojem sedmogodišnjem sinu promijeniti spol usp. https://narod.hr/svijet/majka-iz-texasa-koja-je-htjelapromijeniti-spol-7-godisnjem-sinu-ponovno-izgubila-na-sudu. Čini se da histerija poprima sve šire razmjere, da se širi kao virus i moda, jer, primjerice britanska vlada navodi porast od $4400 \%$ navodno transrodne djece u odnosu na prethodno desetljeće (usp. Jakovac-Lozić D., op. cit. bilj. 42, str. 486), što govori u prilog društvenom fenomenu, a ne biologijskim promjenama i okolišnom utjecaju.

98 Iz ovog razmatranja izuzimamo promjenu spola koja uslijedi kroz kirurški zahvat i odgovarajuću terapiju zbog poremećaja razvoja spola (DSD) uočenog u najranijoj dobi.

99 Riječ je o 8. točki i o mišljenju američkog pedijatrijskog i psihijatrijskog udruženja; usp. JakovacLozić D., op. cit. bilj. 42, str. 486.

100 Države su u obvezi osigurati i pomoć za pronalaženje i povratak djece u obitelji. U novijoj je povijesti poznat slučaj nestanka brojne djece za vrijeme vojne hunte u Argentini; usp. Doek Jaap, A Commentary on the United Nations Convention on the Rights of the Child - Articles 8-9: The Right to Preservation on Identity and the Right Not to be Separated from His or Her Parents, Martinus Nijhof Publishers, 2006., str. 8.

101 Općenito govoreći riječ je o različitim postupcima u vezi s medicinski pomognutom oplodnjom, ali i promjene spola bez medicinskih indikacija, transplantacije fizionomije lica od umrlog donora, eutanazija i sl. 
promidžba zauzimaju mjesto razumu, a na području prava djece istiskuju „osigurač“ koji Konvencija o pravima djeteta naziva „najbolji interes djeteta“. Odrasli, poglavito roditelji osobe su koje upotpunjuju posudu najboljeg interesa djeteta. Ponekad ti sadržaji ne moraju za dijete i njegovu dobrobit biti najprihvatljiviji, pa je i njihova odgovornost za razvoj djeteta (kao pravo i načelo) to veća. Kad se roditelji odlučuju za promjenu spola djeteta „tek tako“ riječ je o nerazumnim roditeljima koji svojim štetnim i ispraznim pomodarskim postupcima krše temeljne funkcije roditeljstva, provocirajući odgovor pravnog sustava u smislu sankcioniranja. Pojam najbolji interes djeteta ne može se tumačiti rastežući ga prema roditeljskim uvjerenjima, već objektivnim sagledavanjem što je za dijete najbolje. Dječji hirovi kao rezultat medijske propagande ili promidžbe novota putem društvenih mreža i drugih internetskih platformi ne smiju biti temelj za ovakve drastične intervencije u zdravlje djece. Određivanje što je za dijete najbolje ne može biti relativno i podložno kriterijima „modernosti“ vremena i prostora u kojem živimo, već mora biti pod vodstvom zdravog razuma ukorijenjenog u moralu i svemu onome što predstavlja osnovu za razvoj djeteta. U protivnome, relativizirajući što je za dijete dobro kroz poglede odraslih, sutra će dovesti do prihvatljivosti dječje pornografije ili pedofilije.

\section{NALAZE LI SE DJEČJA PRAVA NA KRAJU SVOJEGA SVRHOVITOG PUTOVANJA?}

Prava djece kao podvrsta ljudskih prava ${ }^{102}$ zamišljena su kao specijalna prava posebne, ranjive i ovisne skupine ljudi - djece, a radi njihova boljitka i opstanka. Ona nisu njihov ukras (da bismo se mi odrasli dičili svojom ljudskošću!), niti su im dana od nas odraslih (da bismo se mi odrasli hvalili svojom darežljivošću!), već ona postoje radi dostojanstva djeteta kao ljudskoga bića. Putanja razvoja djeteta u rukama je odraslih i nikakva skretanja kojima se narušava djetinje biće nisu dopustiva.

Nakon trideset godina od donošenja Konvencije o pravima djeteta, pred nama je izazov ponovnog promišljanja o cilju i smislu djetetovih prava. Preširoko tumačenje svakog pojedinačnog prava može dovesti do negacije djeteta kao ljudskog bića, a čemu u prilog govori pogrješno shvaćanje djetetova prava na izražavanje vlastita mišljenja. Slikovito rečeno - i djetetovo inzistiranje na prekomjernoj konzumaciji slatkiša dovest će do okusa gorčine. Stoga nam valja, kao akademskim građanima odstupiti od mlakih stavova ${ }^{103}$ i hrabro zauzeti vrijednosne stavove. Klatno dječjih

102 Tako Hrabar D., Prava djece kao prava čovjeka, Naša zakonitost, 1989, 7-8, 865-873.

103 Tako Alderson P., Michael Freeman's views of children's rights and some ideas arising from his views, u. Law in Society: Reflections on Children, Family, Culture and Philosophy, Essays in Honour of Michael Freeman, Diduck A., Peleg N. and Reece H. (eds.), Brill-Nijhof, Leiden/Boston, 2015, str. 206. spominje ,mixed, cautious and inquiring views"; (https://books.google.hr/books?id=ouIzDwAAQBAJ $\& p g=$ AA206\&lpg=PA206\&dq=inherent+values+such+as+honesty,+respect,+justice,+equality \&source =bl\&ots=hjay6Wpb_H\&sig=ACfU3U16mXBEZSq59BsDZii-ygPTe4mpAA\&hl=hr\&sa=X\&ved=2ahU KEwin-uTrzd3nAhUCx4sKHX_nDU0Q6AEwAHoECAcQAQ\#v=onepage\&q=inherent\%20values\%20 such $\% 20$ as $\% 20$ honesty $\% 2 \mathrm{C} \% 20$ respect $\% 2 \mathrm{C} \% 20$ justice $\% 2 \mathrm{C} \% 20$ equality \&f=false; pristup: 19.2 .2020 .). 
prava udaljilo se od srži i smisla postojanja i poštovanja takvih prava utemeljenih na djetetovu prirodnomu dostojanstvu ${ }^{104}$ rušeći pred sobom jednostavan zahtjev pobuditi dijete u djetinjstvu punom poštovanja. Nedjeljive, univerzalne vrijednosti Europske unije - ljudsko dostojanstvo, sloboda i jednakost moraju biti shvaćene s istančanim smislom za dobro čovjeka, osobito djeteta. Ljudsko dostojanstvo je inherentno svakome ljudskome biću, ono je upisano u ljudski kod i vrhunaravno načelo. Sloboda je osjećaj ostvarenja mogućnosti zauzdan slobodama drugih, a jednakost ${ }^{105}$ je političko načelo koje treba shvatiti kao ravnopravnost. Jednakost, naime ne postoji kad je se promatra s individualističkog motrišta neponovljivosti ljudske jedinke. Riječ je o jednakim mogućnostima u jednakim situacijama, a osobito pred zakonom, pa je hrvatski jezični izričaj „,ravnopravnost“" teško zamjenjiv nekim boljim izrazom.

Nametanjem rodne ideologije u svaki, pa i u obrazovni sustav ( $u$ ma kojem obliku i kroz ma kakve sadržaje) udaljujemo se od duhovnih i moralnih vrijednosti na kojima počivaju Vijeće Europe i Europska Unija, granice slobode pojedinca nestaju i ugrožavaju slobode i prava drugih pojedinaca, pa u ime jednakosti i djeca postaju odrasli. To je vidljivo upravo u nerazumijevanju smisla i dosega djetetova prava na izražavanje mišljenje i u rodnoj ideologiji koja ruši sve barijere poznatoga nam svijeta. Rodna ideologija prvi je korak u negaciji djetetovih prava jer je to poimanje ljudskih odnosa nametnuto od strane odraslih, udaljeno od prirode $i$ stvarnosti. Riječ je o štetnom pokretu koji ne štedi svoje žrtve u ime čudnih, ako ne i bolesnih ideja manjeg broja ljudi. Valja se nadati da će se ovaj pogubni tsunami povući na vrijeme i da će razum prevladati, ne dopuštajući nijednoj ideji da nas, osim one ljudskih prava utemeljenih na ljudskome dostojanstvu, vodi naprijed. Djeca će biti najveći gubitnici jer ljudski život ne smije biti predmetom eksperimenta zbog svoje neponovljivosti. Odnosi među ljudima imaju smisla samo kad ih se suobliči poštenju, uvažavanju, pravednosti, jednakosti i suosjećanju ${ }^{106}$.

Zagovornici rodnih ideologija ne priznaju činjenice, već ih proglašavaju politički nekorektnima te ustraju na zbunjivanju djece u trenutku kad, baš zbog dobi i djetinjstva, ionako imaju puno pitanja i dvojbi. ${ }^{107}$ Rodna ideologija ide ukorak s

104 Kako ga spominje Preambula Konvencije o pravima djeteta.

105 Jednakost je jedno od osnovnih prava građana, prvi puta proklamirana u Deklaraciji o pravima čovjeka i građanina 1789., i to kao jednakost u pravima. Slično tomu i Opća deklaracija o ljudskim pravima u čl. 1. govori o jednakosti svih ljudskih bića u dostojanstvu i pravima, a Povelja Europske unije o temeljnim pravima ističe u čl. 20. jednakost svih pred zakonom. Riječ je o jednakosti u korištenju prava, a u vezi sa zabranjenim diskriminatornim osnovama (npr. u Ustavu RH pobrojanih kao: rasa, boja kože, spol jezik, vjera, itd.). Međutim, „Valja držati na umu da to ne znači da svi ljudi imaju u svemu jednaka prava. Očito se prava djece i maloljetnika razlikuju od prava punoljetnih osoba, a politička prava stranaca od prava državljana (građana). Žene nisu dužne služiti vojni rok[u] u miru, te idu u mirovinu ranije nego muškarci, itd. Ali, svi oni imaju pravo jednakosti pred zakonom i nitko od njih ne može biti doveden u slabiji položaj glede korištenja ustavom zajamčenih pravima ni po kojem temelju navedenom u tom ustavnom članku.“; usp, Smerde, B. - Sokol S., Ustavno pravo, Zagreb, 2006., str. 115.

106 Tako Alderson P., op. cit. bilj. 103, str. 206. navodi: „, [h]uman life and relationships can only be understood in relation to inherent values such as honesty, respect, justice, equality and compassion, or their opposites". Autorica, nadalje ističe kako je nemoguće biti vrijednosno neutralan, iako liberalni teoretičari vrlo često izjavljuju da su vrijednosno neutralni.

107 Tako Jakovac-Lozić D., op. cit. bilj. 42, str. 485. 
izmišljanjem individualnih, potpuno usitnjenih, „razmrvljenih novih prava“ koja nemaju veze s čovjekom kao bićem odnosa ${ }^{108}$.

Naziru se ciljevi rodne ideologije koji se ne zadovoljavaju ravnopravnošću spolova, već promiču „obespoljenje“ čovjeka, zamagljujući i naposlijetku eksterminirajući antropologiju čovjeka kao bipolarnog bića uvođenjem nebrojenih tipova rodne pripadnosti. Zatire se ,normalnost“ $i$ antropocentrizam, stvara se neki novi (,vrli“) svijet koji počiva na željama pojedinca ili manjih skupina, stvara se okružje i civilizacija otuđenih ,jastava“, robota-androida bez svojeg mišljenja i odluke. ${ }^{109} 110$ Djeca su u takvoj konstelaciji sredstvo, ali i žrtva koja se prinosi na oltar rodne ideologije. Gdje i kako se to može najbolje osigurati? Upravo umanjenjem roditeljskog utjecaja i odgoja, a preuzimanjem odgoja kroz obrazovne institucije i programe. ${ }^{111}$ Svjedoci smo paklenog plana mogućnosti oduzimanja roditeljskih prava onim roditeljima koji se ne podvrgavaju zadanoj ideji preoblikovanja djece u ambisu rodne ideologije. ${ }^{112}$ To bi moglo ilustrativno podsjećati na zlo proživljenih totalitarnih sustava kad su ideologije preuzimale odgovornost za odgoj djece. Približavamo li se tomu, slijedeći primjer nekih zapadnih zemalja? Rodna ideologija i promjena spola u djece predstavlja do sada najradikalniju manipulaciju djecom ili kako autorica Jakovac-Lozić kaže ,,vrhunac manipulativnih eskapada odraslih nad djecom“. ${ }^{113}$ Riječ je o neoliberalnom totalitarizmu koji prvo mora zarobiti djecu da bi potpuno preuzeo vlast nad svima. On to čini različitim sredstvima, a jedno od njih je širene rodne ideologije i upravljanje dječjim mišljenjem.

Pitamo se što je do sada nedostajalo djeci koja su bili dječaci ili djevojčice po spolu, tako rođeni, koji su imali jednu majku i jednog oca, a ne transrodne roditelje ili dvojicu očeva ili pak dvije majke? Novim tipovima obiteljskih zajednica - da bi to bile - nedostaju djeca. Iz tog razloga njihovi zagovornici inzistiraju na udomljavanju, posvojenju ili medicinskoj oplodnji (osobito surogatnom majčinstvu) kao načinu kako će nastati potpuna obitelj. No, tu se zanemaruje dijete kao središnja ,figura“ i njegova dobrobit, koje antropološki, biološki i psihološki gledano treba majku i oca.

108 Usp. Schooyns, Skriveno lice UN-a-Prema novoj svjetskoj vladi, Verbum, Split 2006, str. 107. cit. prema Jakovac-Lozić D., ibid. , str. 515.

109 Peterson J. B., „, 12 pravila za život - protuotrov kaosu“, Verbum, Split, 2018. na str. 172. i d. navodi kako je postmodernost stvarnost u kojoj živimo u kojoj ljudi više ne razmišljaju svojom glavom; usp. Jakovac-Lozić D., op. cit. bilj. 42, str. 532.

110 Premda znanstvena promišljanja treba vrjednovati kroz znanstvene publikacije, činjenica je da nova vrsta medija kao što su internetski portali daje priliku znanstvenicima da širu javnost upozore na nove društvene promjene. U ovo o čemu pišemo uklapaju se mnogi intervjui koje daje astrofizičar Korado Korlević kad govori o kaosu u kojem živimo, a koji prijeti opstanku civilizacije. On ključ opstanka vidi u djeci novog doba ako prepoznaju vrlinu znanja i poželjnost promjena koje će nas sačuvati od potpunog potonuća i apokalipse; usp. http://novilist.hr/Znanost-i-tehnologija/Znanost/Dramaticno-upozorenjeKorada-Korlevica-Dragi-moji-usli-smo-u-slijepo-crijevo-civilizacije. Recentni pandemijski učinak covid19 zaraze pokazuje svu krhkost svijeta i potrebu za preoblikovanjem društvenih odnosa.

111 Tako zaključuje i Lew Rockwell, američki pisac i znanstvenik; usp. Jakovac-Lozić D., op. cit. bilj 42, str. 487.

112 Jakovac-Lozić D., op. cit. bilj. 42 navodi takav primjer u državi Ohio, SAD. Usp. Dave Bohon, Ontario Passes Law to Take Children From Parents Who Oppose „Gender Expression“", htpps://www. ola.org/en legislative-business/bill/parliament-41/session-2/bill-89, cit. prema bilj. 75.

113 Jakovac-Lozić D., op. cit. bilj. 42, str. 527. 
Djecu se kroz rodnu ideologiju stavlja u poziciju žrtava ${ }^{114}$ radi ostvarenja ciljeva odraslih i promjene paradigme tradicionalne obitelji.

$\mathrm{Na}$ kraju, valja podsjetiti kako određeni radikalni stavovi postmodernoga doba malo -pomalo zauzimaju prostor našeg uma i ono što se jučer činilo nemogućim, danas je prihvatljivo, sutra već možda i poželjno i ozakonjeno. ${ }^{15}$ Postmoderno društvo je licemjerno i posramljujuće, sebeljubno. Ono oblikuje zapadnu civilizaciju s čvrstom odlukom da je promijeni, bez obzira što zapadnjački standardi mogu aktualno štetiti djeci ${ }^{116}$. U samoj je srži postmodernoga Zapada rodna ideologija i ne treba puno razmišljanja da vidimo da su vrata pakla odškrinuta.

Pitamo se: je li ovo rugalica, šala ili nakaradno zlo? Bilo kakav odgovor bio nijedan nije dobar za čovječanstvo, za obitelj, a ponajmanje za djecu. Sve što ne valja propadne.

Prava djece su neobično važna, ona su ,ugrađena u dječja tijela“"117. Odvajkada, pa tako i danas, djeca bivaju ugrožena djelovanjem odraslih, ${ }^{118}$ pa je njihov opstanak i razvoj ugrožen i u budućnosti. Djeca čine temelj zdrave budućnosti i izmaknuti ovu ciglu iz bedema života opasno je.

Svijet se radikalno promijenio u posljednjih 30 godina. Konvencija o pravima djeteta u vrijeme svojeg donošenja odražavala je do tada najcjelovitiji i najbolji modus zaštite djece u svijetu. No, ona je previdjela ili hotimice ostavila određene napukline koje nisu izdržale kušnju vremena i danas, zbog navale globalizacijskog procesa prijete urušavanju cjelokupnog sustava prava djece. Znanstvene rasprave spominju divergentne čimbenike o kojima se nije vodilo dovoljno računa pri nastajanju Konvencije o pravima djeteta. Riječ je o kršenju različitih konvencijskih prava, a čimbenici koji to omogućuju neposredno ili posredno su: globalizacija u okvirima

114 Ili kako to Aleksandra Korać Graovac kaže: „Djeca nisu ledolomci da bi se partneri osjećali bolje pa ćemo im dati prava u odnosu na djecu zato da bi njihova zajednica bila priznatija u društvu. Bojim se da se djeca ovdje zapravo koriste kao sredstvo, a ne kao cilj. Nije cilj zaštititi prava djece, nego da se istospolni partneri osjećaju bolje i prihvaćenije.", usp. https://www.vecernji.hr/premium/ne-trebaizmisljati-skrb-o-djeci-za-homoseksualce-629163.

115 Riječ je eugenici, odnosno usmrćivanju djece sa sindromom Down; v. napise u medijima o ubijanju takve djece na Islandu, Danskoj i paradržavi ISIS (npr. https://www.jutarnji.hr/life/obitelj-i-djeca/ velika-svjetska-kontroverza-na-islandu-trudnocu-prekida-cak-98-majki-koje-znaju-da-ce-dijete-imatiporemecaj-a-i-u-hrvatskoj-je-taj-postotak-visok/6851181/; https://www.bitno.net/vijesti/kada-je-ludostsavrsena-danska-zemlja-bez-down-sindroma; http://www.novilist.hr/Komentari/Kolumne/KolumnaMarina-Miletica/Downov-sindrom-kao-uteg-licemjernog-drustva; https://www.fokus.ba/vijesti/globus/ isis-naredio-ubijanje-djece-sa-downovim-sindromom/157037/.

116 Tako Kaufman N. H., The status of children in international law, u: Globalisation and Children, N. Kaufman \& I. Rizzini (eds.), Leiden: Kluwer, 2002., cit. prema M. Freeman, bilj. 6, str. 12.

117 McGillivray A., The Long Awaited: Past Futures of Children's Rights, u: The Future of Children's Rights, M. Freeman (ed.), bilj. 6, str. 97.

118 Riječ je o svemu što ,proizvode“ doslovce i u prenesenom smislu odrasli: uništeni okoliš s toksinima koji utječu na kognitivni i neurološki razvoj djece, medijsko okruženje (video-igrice, mobiteli, sms-ovi, kompjutori, iPod, MP3 uređaji uz njihovo pretjerano korištenje), scene nasilja, pretjeranost oglašavanja i poticanje konzumerizma, što također uzrokuje neurološke štete, odabir spola budućeg djeteta kao dio nesankcionirane predimplantacijske dijagnostike, transfer višestrukih trudnoća koji završavaju preranim rođenjem djece i njihovim pobolom i smrtnošću osnažujući nesputano pravo roditelja na odluke o prokreaciji, samo su neki od primjera ,fikcijske znanosti i društvenog inženjeringa“, usp. ibid., str. 97 i d. 
svjetskog razvoja, okolišne i klimatske promjene, život djece u megapolisima, ${ }^{119}$ HIV/AIDS, nekontrolirani napredak medicine u području pomognute oplodnje (s tim u vezi pravo djeteta na saznanje vlastitog podrijetla), pobačaji učinjeni zbog odabira spola djeteta, ${ }^{120}$ spoznaje o povećanju broja djece oboljele od neuroloških bolesti zbog uporabe određenih lijekova ${ }^{121}{ }^{122}$. Proponenti zaštite djece i njihovih prava zagovaraju pomlađivanje ${ }^{123}$ Konvencije o pravima djeteta koje ce uzeti u obzir sve ono što se kristaliziralo kao nepostojeći odgovor na suvremene izazove, zato što je svijet današnjeg djeteta nemjerljiv s vremenom usvajanja Konvencije o pravima djeteta koje bijaše „razdoblje optimizma““. ${ }^{124}$ Promjene bi trebale započeti $\mathrm{s}$ definicijom djeteta i povišenjem dobne granice, ${ }^{125}$ te je proširiti na spomenuta područja u kojima se ne štiti djecu. Ne smije se smetnuti s uma činjenica da je globalni učinak Konvencije o pravima djeteta samo relativan i izraz kako iskrenih nastojanja za poboljšanjem položaja djece, ali u ponekim slučajevima i lažnih obećanja koje su države potpisnice preuzele. Upitno je može li jedan te isti tekst funkcionirati na isti način u potpuno različitim kulturama? Mnogobrojni su čimbenici koji utječu na izazove u pojedinim zemljama i zato daju nejednaku sliku o pravima djece u svijetu. ${ }^{126}$

Konvencija o pravima djeteta na svoj je način ambivalentna. Ona je s jedne strane ,živući instrument“ i prilagođuje se novim situacijama, ${ }^{127}$ a s druge strane nije relevantna za zbilju naše djece i adolescenata, ${ }^{128}$ jer ne daje odgovor na nove izazove. Usprkos enormnom doprinosu za poboljšanje prava djece u svijetu ona danas više nije svetinja i predstavlja „,sasvim novu realnost“"129. Tumačenje njezinih

119 Spominje se da više od polovice svjetskog stanovništva živi u velikim gradovima koje odlikuju prenapućeni slamovi i loša kvaliteta života, usp. Veerman Ph. E., op. cit. bilj 11, str. 38.

$120 \mathrm{Ph}$. E. Veerman upozorava na posebnu pažnju koju bi trebalo pokloniti prenatalnoj zaštiti djece, pozivom na Preambulu Konvencije zbog sve većeg broja trudnica ovisnica jer je riječ o ,,prenatalnom zlostavljanju djece“, ibid, str. 18.

121 Veerman Ph. E. ibid. spominje ADHD, str. 40.

122 Ibid., str. 35-40.

123 Ph. E. Veerman navodi „Convention looks old“, ibid., str. 42.

124 Ibid., str. 40.

125 Veerman Ph. E., ibid., str. 17, zagovara povišenje na 24 godine na temelju neuroznanstvenih spoznaja o razvoju mozga i promjena u socijalnom okruženju. Autor citira znanstvenike koji se iz socijalnih razloga i produljenja sazrijevanja djeteta zbog društva u kakvom živimo (,, the more 'modern' the society, the later people will be ready to be seen as an adult for longer than previously") zalažu za redefiniranje pojma dijete, te govore o djetinjstvu kao društvenom konstruktu, usp. str. 20. Razvojni psiholog Michael Westenberg tvrdi da adolescent vrlo često zbog razvoja mozga i duševnog razvoja ne može učiniti valjani izbor; usp Veerman Ph. E., str. 19.

126 Kao čimbenici se navode: ljudski i financijski izvori, socijalna stabilnost, postojanje i učinkovitost propisa o pravima djece, škodljive prakse u odnosu na djecu ukorijenjene u društvu, zemljopisne razlike (u smislu prenapučenosti stanovništva, izolirane države-otoci, klimatski utjecaji), društveno-političko uređenje i sl.; usp. Khazova O. A. \& Mezmur B. D, UN Committee on the Rights of the Child-Reflections on Family Law Issues in the Jurisprudence of the CRC Committee, u: International Survey of Family Law 2019., Brinig M. (ed.), Intersentia, Cambridege - Antwerp - Chicago, 2019, str. 306.

127 Tako Freeman, M., op. cit. bilj. 6, str. 6. ovaj atribut iznosi zbog prilagodbe pravnih sustava da zabranu nasilja nad djecom (iz čl. 19 Konvencije) prošire i na zabranu šamaranja djece.

128 Veerman Ph. E., op. cit. bilj. 11, str. 42: „... the Convention often does not look relevant for the realities of our children and adolescents. “

129 Ibid., str. 16. 
odredaba u novim okolnostima prisvojili su si oni koji žele opravdati svoje ideološke ciljeve, mada ih Konvencija nije imala na umu. ${ }^{130}$ Jedna od štetnih realnosti i izravan napad na prava djece jest rodna ideologija koja nameće neke nove destruktivne vrijednosti naspram plemenita cilja zaštite djece i njihove dobrobiti te odgovorne uloge roditelja u razvoju djece. Za pojedine skupine koje su se na Zapadu nametnule kao slobodnomisleće, napredne i jedine ispravne, makijavelističko sredstvo - prava djeteta, i osobito njegovo pravo na izražavanje mišljenja, opravdavaju cilj - stvaranje novog svijeta utopijske jednakosti bez spola i odgovornosti u pletori individualizma, sebeljublja, stvarne netolerancije, gaženja vladavine prava. Čini se da je prvi čin nestvarne drame otpočeo.

\section{ZAKLJUČAK}

Postmoderno doba obilježeno je mnogim napredcima ${ }^{131}$, ali je u sebi skrilo i klicu propasti čovjeka kao ontološkog bića. Premda ideje, teško bi bilo reći pozitivne vrijednosti postmoderne traju već nekoliko desetljeća, čini se da su njezine razorne posljedice i negativni učinci na društvo vidljivi upravo u ovome trenutku. U trećem tisućljeću dolazi do velike divergencije u odnosu na ustaljene vrijednosti o čemu se sve jasnije i glasnije govori. Vrijednosti kao što su ljudsko dostojanstvo i obitelj zatiru se i izobličuju. Uz pomoć rodne ideologije koja je uzela zamaha, razaraju se osnovne odrednice društva - bipolarnost čovjeka i obitelj kao temeljna jedinica društva. Budući da je u temelju obitelji dijete, promjena obiteljskoga koda mora otpočeti s promjenama koje će negirati dijete i djetinjstvo. Obitelj prirodno nastaje prokreacijom (ili rjeđe posvojenjem) koja je moguća samo između žene i muškarca. Kad je Konvencija o pravima djeteta potrebe djeteta uzdignula na razinu prava, ona je htjela dijete zaštititi u odrastanju i sazrijevanju, omogućujući mu uvjete za opstanak i razvoj. Među endogenim čimbenicima ističemo roditelje kao najvažnije osobe za opstanak i razvoj djeteta. Premda Konvencija spominje roditelje ${ }^{132}$, a ne ženu (majku) i muškarca (oca) kao najodgovornije osobe, nepobitno je pred očima imala prirodne odnose i obitelj koju čine majka, otac i dijete (djeca). Nemoguće je (bilo)

130 Sličnu sudbinu doživljava i Konvencija za zaštitu ljudskih prava i temeljnih sloboda koju se tumači kao živući instrument i prilagođava novonastalim društvenim odnosima (osobito u presudama Europskoga suda za ljudska prava).

131 Benedikt XVI upozorava: „Novi je vijek tražio svoj put među temeljnim pojmovima „napredak“ i „sloboda“. Ali što je napredak? Danas vidimo da napredak može biti i rušilački. Utoliko moramo razmišljati o tome koje kriterije moram naći da bi napredak uistinu bio napredak.", Benedikt XVI, Svjetlo svijeta, Verbum, Split, 2010, str. 59.

132 U čl. 5. Konvencija o pravima djeteta spominje odgovornosti, prava i dužnosti roditelja ili, kad je to moguće, članova šire obitelji ili zajednice u skladu s lokalnim običajima, zakonske zastupnike ili druge osobe koje su pravno odgovorne za dijete. Dakle, Konvencija ne definira tko čini obitelj upravo zbog različitih oblika i varijacija. Međutim, kad Rezolucija Vijeća za ljudska prava Ujedinjenih naroda „Zaštita obitelji“ (br. 26/11) od 25. lipnja 2014. reafirmira obitelj kao „prirodnu i temeljnu jedinicu društva“ onda per definitionem podrazumijeva majku i oca. 
zaključiti kako majka i otac nisu najbolji odgojitelji vlastita djeteta, ${ }^{133}$ kako postoji nešto ili netko drugi koji bi to činio bolje. Rodna ideologija niječe i obezvrjeđuje ili barem neutralizira odnosno ne naglašava spolnu ulogu roditelja pri odgoju djece. ${ }^{134}$ Odluke odraslih da djeci nadomjeste roditeljstvo s osobom istoga spola moraju utjecati na identitet djeteta u smislu njegova biološkog podrijetla kakvo mu jamči čl. 7. Konvencije o pravima djeteta. Razarajuća je moć banalnosti koju se u ovome slučaju spoznaje kroz neograničenu slobodu odraslih da odlučuju o vrijednostima koje djetetu pripadaju: dolazi do trenja između djeteta i samoga svijeta, nameće mu se nešto što ono samo nikada ne bi odabralo. Nevoljkost hrvatskoga pristupa u smislu omogućavanja istospolnog roditeljstva opravdava se navodnom nezrelošću društva da prihvati rodnu ideologiju odnosno istospolne roditelje, podmećući ideju o sazrijevanju društva u nekome budućemu vremenu. Takvo licemjerno ispričavanje zamjena je za jasnu tvrdnju da dijete nedvojbeno treba majku i oca te da rodna ideologija nije prihvatljiva ni s jednog aspekta. Djetetovo pravo na identitet mora podrazumijevati, upravo danas kad rodna ideologija gura svoje vrijednosti u prvi plan, pravo na oba spolom različita roditelja, a ne samo pravo na ime i stjecanje državljanstva. U tome smislu treba prionuti uz temeljne ciljeve Konvencije o pravima djeteta, a to su očuvanje djeteta i njegovih prava te klasičnog tipa nuklearne obitelji.

Pravo djeteta na identitet ugroženo je i pogrješnim tumačenjem djetetova prava na izražavanje mišljenja, a osobito u odnosu na pravo na zdravlje odnosno promjenu djetetova spola. Konvencija o pravima djeteta pravo na zdravlje razrađuje kroz pojedine javnozdravstvene segmente zdravlja ${ }^{135}$ čime upozorava na različite probleme koji mogu ugroziti i živote djece. Promjena identiteta djeteta promjenom spola, s ili bez njegova pristanka (odnosno izraženoga mišljenja) neposredno je u sukobu s idejom i načelom zaštite najboljeg interesa djeteta. Već je prethodno spomenuto da pojedini roditelji olako i neodgovorno shvaćaju djetetove želje za promjenom spola (koje su najčešće dio normalne „krize identiteta“ djeteta), ne razmišljajući da time mogu biti ugroženi život i zdravlje djeteta za vrijeme djetinjstva, i to u tjelesnome i duševnome smislu, i kasnije u fertilnoj dobi s dalekosežnim negativnim prokreacijskim, a moguće i šire zdravstvenim učincima. Sve u ime rodne osviještenosti roditelja i društva!

133 Dakako mislimo na dobre i sebedarujuće roditelje, a ne one prema kojima se izriču različite vrste sankcija.

134 Jedan od dokaza smjera u kojem zapadno društvo danas ide su pravni sustavi koji omogućuju upis roditelja djece u spolno (,,rodno“) neutralnom izričaju (kao „,roditelj 1“ i ,roditelj 2“), kako je to primjerice moguće u Francuskoj i Njemačkoj, a sve su glasniji zahtjevi (u nekim nordijskim zemljama) da se prilikom upisa rođenja djeteta u matice rođenih izostavi upis spola.

135 U čl. 24. spominju se: najviša moguća razina zdravlja, ozdravljenje i oporavak djece, zdravstvene usluge i mjere radi smanjenja smrtnosti novorođenčadi i djece, osiguranje medicinske pomoći i primarne zdravstvene zaštite, sprječavanje bolesti, neishranjenosti, dostupnost prehrane i pitke vode, prenatalna i postnatalna zdravstvena skrb majki, javnozdravstvene mjere i razvoj preventivne zdravstvene zaštite, otklanjanje tradicionalnih postupaka koji štete djeci i posebna ugroženost zdravlja djece u zemljama u razvoju. 
Djetetovo pravo na izražavanje mišljenja je vrijedno pravo, no nije apsolutnog značenja upravo zato što dijete ne može zbog svoje dobi biti odgovorno. Sloboda nije proizvoljnost i treba je naučiti poimati kao odgovornost, ${ }^{136}$ sloboda i odgovornost idu zajedno ${ }^{137}$. Trebamo se u svemu, pa tako i u pogledu rodne ideologije i njezina utjecaja na djecu zapitati što je ispravno, a ne što je moguće. ${ }^{138}$

Ispravan je holistički pristup Konvenciji o pravima djeteta, no i pristup djetetu treba biti holistički. Mnoga prava zato što počivaju na djetetovim potrebama međusobno se nadopunjuju i prelijevaju tvoreći sliku i priliku zadovoljnog djeteta. Nijedno pravo nije važnije od drugoga, ona su međusobno povezana i uvjetovana. Stoga, zauzimati se za apsolutno pravo djeteta na izražavanje mišljenja može imati negativan učinak, kao što i apsolutna odgovornost roditelja za dijete može biti pogubna. Ali, pogubne mogu biti i politike koje kroz rodnu ideologiju izvrću poimanja prema neprirodnome. Dakle, racionalan pristup nije arhaičan ni retrogradan, već onaj koji uvažava ljudsko i djetetovo dostojanstvo i traži smisao u poretku stvari. U protivnome, nisu bili u pravu svi oni koji su govorili da su djeca budućnost svijeta i da Konvencija o pravima djeteta predstavlja najvažniji međunarodni dokument za zaštitu djece.

\section{SAŽETAK}

O pravima djece ne može se govoriti zaobilazeći Konvenciju o pravima djeteta. Od njezina usvajanja prošlo je tri desetljeća, pa se polako pojavljuju problemi koje ova Konvencija nije riješila iz jednostavnog razloga što nije bila u tolikoj mjeri dalekovidna. Problemi djece današnjeg svijeta nisu jednaki onima prije donošenja Konvencije o pravima djeteta, a prisutan je i negativan utjecaj promišljanja o djeci i njihovim pravima kroz zapadnjačku prizmu. Različiti teoretičari zauzimaju divergentna promišljanja o svrsi i opstanku Konvencije o pravima djeteta, uočavajući radikalne promjene koje su u tijeku. S obzirom da nijedan pravni dokument ne živi izvan svijeta i vremena, već naprotiv društvo i institucije, ovisno o okolnostima, nastoje starije pravne izričaje prilagoditi novim vremenima i izazovima, pa se nerijetko u teoriji govori o karakteru međunarodnih ugovora kao živućem propisu (living instrument). Međutim, ta kovanica može biti sredstvo ostvarenja skrivenih i zlih ciljeva. Kroz trigon prava djeteta: na izražavanje mišljenja, njegovo pravo na zdravlje i pravo na identitet, vidljiv je škodljiv utjecaj rodne ideologije koja nastoji promijeniti društvene obrasce ne samo između odraslih osoba, već i u odnosu na djecu. Vidljivo je to posebice u odnosu na promjenu spola djeteta koju omogućuju

136 Op. cit. bilj 130., str. 57.

137 Ibid., str. 127.

138 Benedikt XVI, ibid., str. 60 piše: „Što je stvarno napredak? Je li napredak kada mogu razarati? Je li napredak kada sam mogu načiniti, selektirati i ukloniti čovjeka? Kako se može etički i ljudski ovladati napretkom? Ali nije potrebno iznova promisliti samo kriterije napretka. Pored napretka i spoznaje posrijedi je i drugi temeljni pojam nova vijeka: sloboda. Sloboda koju se shvaća kao slobodu da se sve može činiti. Iz ovakva mišljenja proizlazi zahtjev da se znanost ne može dijeliti. To znači: ono što se može, mora se $\mathrm{i}$ smjeti činiti. Sve bi drugo bilo protiv slobode. ... danas imamo neravnotežu koja se odražava u plodovima napretka koji nije bio moralno promišljen." 
pravni sustavi, a pojedini, neodgovorni roditelji podržavaju. U tu svrhu ističe se pravo djeteta na izražavanje mišljenja, u ovome slučaju u odnosu na njegovu želju da promijeni spol, bez promišljanja o tome koliko je dijete nezrelo i koliko je to u biološkome smislu štetno za dijete kad odraste. Pravo djeteta na identitet dovodi se u pitanje, jer promjenom spola i rodno-ideološkim pristupom prema kojemu spol nije bitan, već je determinirajući čimbenik rod, anulira se bipolarna stvarnost, a na kraju i obitelj koju čine majka, otac i djeca. Takvo pogubno promišljanje izravno se sukobljava s dostojanstvom djeteta i služi tomu da društvo u najširem smislu prihvati rodnu ideologiju neovisno o tome što ona izravno krši djetetov najbolji interes. Nažalost, svjedoci smo da su različite međunarodne i europske institucije generatori i promicatelji takvog nakaradnog pristupa. Čini se da zahtjevi za promjenom nekih odredaba Konvencije o pravima djeteta imaju svoje opravdanje ako bi takve promjene težile za ponovnim uvažavanjem djetetova inherentnog dostojanstva i osnaženja obitelji koju čine majka i otac. Pritisci kojima su djeca izložena kroz različita sredstva predstavljaju oblike manipulacije djecom i njihovim djetinjstvom, uzevši dodatno u obzir i činjenicu da premda sva prava djece pripadaju svoj djeci svijeta, zapadnjački obrazac u tumačenju tih prava, u mnogome okrnjuje plemenit cilj donošenja Konvencije o pravima djeteta.

\section{LITERATURA}

1. Alderson P., Michael Freeman's views of children's rights and some ideas arising from his views, u: Law in Society: Reflections on Children, Family, Culture and Philosophy, Essays in Honour of Michael Freeman, Diduck, A., Peleg, N. Reece, H. (eds.), Brill-Nijhof, Leiden/Boston, 2015.

2. Alvaré H. M., The sexualization of children: a massive problem with insufficient solutions, u: Marriage, Children and Family, Modern challenges and Comparative Law Peerspective, Grzegorz Blicharz ed., Wydawnictwo instytutu wimiaru sprwedliwosci, Warzawa, 2019.

3. Augustin A., Ispovijesti, KS, 2002.

4. Benedikt XVI, Svjetlo svijeta, Verbum, Split, 2010.

5. Bognar B., Čovjek i odgoj, Metodički ogledi, 22, 2, 2015, 9-37.

6. Bognar L., Metodika odgoja, Osijek, 2001, Sveučilište J.J. Strossmayera u Osijeku

7. Cvjetko M., Opisi i definicija kulture, https://www.pilar.hr/wp-content/images/ stories/dokumenti/studije/16/milanja_kk_011.pdf

8. Hrabar D., The Legal Protection of the Best Interests of the Child, u: European Training on the Convention on the Rights of the Child, ed. Rädda Barnen/Swedish Save the Children \& Centre for Social Policy Initiative, Zagreb, 1998.

9. Jakovac-Lozić D., ,,Rod“ " protiv „,spola“-polazište na putu razaranja braka i obitelji, Zbornik radova Pravnog fakulteta u Mostaru, Petnaesto međunarodno savjetovanje „Aktualnosti građanskog i trgovačkog zakonodavstva i pravne prakse“, 2017.

10. Jakovac-Lozić D., Nastojanja na putu „rane seksualizacije“ djece - interes djeteta ili potreba odraslih, Zbornik radova Pravnog fakulteta u Splitu, 57, 2020, 2, 479-533. 
11. Jaap D., A Commentary on the United Nations Convention on the Rights of the ChildArticles 8-9: The Right to Preservation on Identity and the Right Not to be Separated from His or Her Parents, Martinus Nijhof Publishers, 2006.

12. Dulčić D., Masovni mediji i postmoderno društvo, Media, culture and public relations, 5, 2014, 1, http://www.matica.hr/vijenac/373/danas-se-zivot-svodi-na-igru-22198

13. Freeman M., Children's Rights Past, Present, and Future: Some Introductory Comments, u: The Future of Children's Rights, Michael Freeman (ed.), Brill - Nijhoff, Leiden - Boston, 2014.

14. Hrabar D., Odjek roditeljskih vjerskih i filozofskih uvjerenja na odgoj i obrazovanje djece u hrvatskoj legislativi, Zbornik Pravnog fakulteta u Zagrebu, 68, 2018, 3-4, 319-336.

15. Hrabar D., Istanbulska konvencija - zamke rodne ideologije, Zagreb, 2019.

16. Hrabar D., Obiteljsko pravo u sustavu socijalne skrbi, Narodne novine, 2019.

17. Hrabar D., Prava djece kao prava čovjeka, Naša zakonitost, 1989, 7-8, 865-873.

18. Peterson J. B., 12 pravila za život - protuotrov kaosu, Verbum, Split, 2018.

19. Kaufman N. H., The status of children in international law, u: Globalisation and Children, N. Kaufman \& I. Rizzini (eds.), Leiden: Kluwer, 2002.

20. Koprek I., Razarajući čimbenici braka i obitelji, Bogoslovska smotra, 85, 2015, 3, 759-778.

21. Lansdown G., The evolving capacities of the child, Innocenti Research Centre, UNICEF/Save the Children, Florence, 2005 https://www.unicef-irc.org/publications/ pdf/evolving-eng.pdf

22. Lisičar H., Pravni aspekti zaštite maloljetnika u elektroničkim medijima, u: Prava djece - multidisciplinarni pristup, Hrabar, D, (ur.), Zagreb, 2016., 119-145.

23. Matić D., Postmodernistička zbrka ili gdje je nestao čovjek, http://www.laudato.hr/ Tko-je-ovdje/Osvrti/Filozofijom-protiv-obmana/Postmodernisticka-zbrka-ili-gdje-jenestao-covjek.aspx

24. McGillivray A., The Long Awaited: Past Futures of Children's Rights, u: The Future of Children's Rights, M. Freeman (ed.), Children's Rights Past, Present, and Future: Some Introductory Comments, u: The Future of Children's Rights, Michael Freeman (ed.), Brill - Nijhoff, Leiden - Boston, 2014.

25. Omejec J. Konvencija za zaštitu ljudskih prava i temeljnih sloboda u praksi Europskog suda za ljudska prava, Strasbourški acquis, Zagreb, Novi informator, 2014.

26. Pećnik N., Suvremeno roditeljstvo i prava djeteta, u: Prava djece-multidisciplinarni pristup, Hrabar, D. (ur.), Zagreb, 2016.

27. Peleg N., Reconceptualizing the Child's Right to Development: Children and the Capability Approach, u: The Future of Children's Rights, Michael Freeman (ed.), Brill - Nijhoff, Leiden - Boston, 2014.

28. Mausfeld R., Angst und Macht - Herrschaftstechniken der Angsterzeugung in kapitalistischen Demokratien, Westend, $a$. $n$.

29. Schooyans M., Skriveno lice UN-a-Prema novoj svjetskoj vladi, Verbum, Split, 2006.

30. Smerdel B. - Sokol S., Ustavno pravo, Zagreb, 2006., str. 115. 
31. Smith R., A Universal Childhood?, London: Palgrave Macmillan, 2012.

32. Giroux H. \& Pollock G., The Mouse That Roared, u: Freeman, M., Children's Rights Past, Present, and Future: Some Introductory Comments, u: The Future of Children's Rights, Michael Freeman (ed.), Brill - Nijhoff, Leiden - Boston, 2014.

33. Tobin J. Justifying Children's Rights, u: The Future of Children's Rights, Michael Freeman (ed.), Brill - Nijhoff, Leiden - Boston, 2014.

34. Veerman Ph. E., The Aging of the UN Convention on the Rights of the Child, $\mathrm{u}:$ The Future of Children's Rights, Michael Freeman (ed.), Brill - Nijhoff, Leiden - Boston, 2014.

35. Vukasović A., Etika, moral, osobnost: moralni odgoj u teoriji i praksi odgajanja, Zagreb, 1993.

36. Young-Bruehl E., Childism, New Haven, Yale University Press, 2012.

37. Hrvatska enciklopedija LZ Miroslav Krleža, Zagreb, a. n., sv. 6 http://www. enciklopedija.hr/Natuknica.aspx?ID=32241.

\section{PRAVNI AKTI}

1. Konvencija o pravima djeteta, Sl. list SFRJ, 15/90, NN MU, 12/90, 20/97, 4/98, 13/98)

2. Konvencija Vijeća Europe o sprečavanju i borbi protiv nasilja nad ženama i nasilja u obitelji, Narodne novine, MU, br. 3/2018

3. Obiteljski zakon, Narodne novine, br. 103/2015, 98/2019

4. General Comment no. 12 (2009) The right of the child to be heard, par. 2. CRC/C/ GC/12, 20. 7. 2009, https://www.refworld.org/docid/4ae562c52.html

\section{MREŽNI IZVORI}

1. https://rm.coe.int/168066cff8

2. https://www.dailymail.co.uk/news/article-7146961/Leading-Oxford-academicsblast-LGBT-charity-Stonewalls-trans-awareness-training.html

3. http://assembly.coe.int/nw/xml/XRef/Xref-XML2HTML-en.asp?fileid=19162.

4. https://www.acpeds.org/the-college-speaks/position-statements/gender-ideologyharms-children

5. http://www.europarl.europa.eu/doceo/document/A-8-2018-0173_HR.html

6. https://www.dailymail.co.uk/femail/article-7296803/Parents-reveal-childrentransgender.html?ns_mchannel=rss\&ico=taboola_feed\&fbclid=IwAR1DBGVXk8ZowzjHq-knsDv-ccXclALPVX81jv3glUEIDGFhL34bRuaVLA

7. https://www.novizivot.net/4-godisnje-dijete-trazi-promjenu-spola-roditelji-pristaju/

8. https://www.24sata.hr/fun/roditelji-vec-dvije-godine-ne-zele-otkriti-spoldjeteta-123240

9. https://narod.hr/svijet/majka-iz-texasa-koja-je-htjela-promijeniti-spol-7-godisnjemsinu-ponovno-izgubila-na-sudu

10. https://books.google.hr/books?id=ouIzDwAAQBAJ\&pg=PA206\&lpg=PA206\&dq $=$ inherent+values + such+as+honesty, + respect, + justice,+ equality \&source $=b l \& o t s=h$ 
jay6Wpb_H\&sig=ACfU3U16mXBEZSq59BsDZii-ygPTe4mpAA\&hl=hr\&sa=X\& ved=2ahUKEwin-uTrzd3nAhUCx4sKHX_nDU0Q6AEwAHoECAcQAQ\#v=onep age \&q=inherent $\% 20$ values $\% 20$ such $\% 20$ as $\% 20$ honesty $\% 2 \mathrm{C} \% 20$ respect $\% 2 \mathrm{C} \% 20$ justice $\% 2 \mathrm{C} \% 20$ equality \&f=false

11. http://novilist.hr/Znanost-i-tehnologija/Znanost/Dramaticno-upozorenje-KoradaKorlevica-Dragi-moji-usli-smo-u-slijepo-crijevo-civilizacije

12. htpps://www.ola.org/en legislative-business/bill/parliament-41/session-2/bill-89

13. https://www.vecernji.hr/premium/ne-treba-izmisljati-skrb-o-djeci-za-homoseksualce629163

14. https://www.jutarnji.hr/life/obitelj-i-djeca/velika-svjetska-kontroverza-na-islandutrudnocu-prekida-cak-98-majki-koje-znaju-da-ce-dijete-imati-poremecaj-a-i-uhrvatskoj-je-taj-postotak-visok/6851181/

15. https://www.bitno.net/vijesti/kada-je-ludost-savrsena-danska-zemlja-bez-downsindroma

16. http://www.novilist.hr/Komentari/Kolumne/Kolumna-Marina-Miletica/Downovsindrom-kao-uteg-licemjernog-drustva; https://www.fokus.ba/vijesti/globus/isisnaredio-ubijanje-djece-sa-downovim-sindromom/157037/

\section{POSTMODERN ERA AS A FORERUNNER TO NEGATION OF CHILDREN'S RIGHTS}

Children's rights have been entrenched into many international documents. The most obvious is the Convention on the Rights of the Child. The period of its application (thirty years) warrants analysis of its purpose and observing the aims which it wanted to achieve as well as the dangers lurking today to destroy the overall system. The world children live in today is in many segments incomparable with the times in which the afore mentioned Convention concluded the legal status of children. Among the many rights which were endangered by postmodern movements are children's rights to freedom of expression which are linked to their right to change genders (within the framework of health rights) and the right to identity. Gender ideology over the last few years has opened up the way towards societal changes, not only in relation to adults, but also to children, their upbringing and family formation. Assaults to this are more and more evident and are unfortunately supported by steps by institutions (in the United Nations, European Union and Council of

Europe) despite the fact of transparency of goals aimed at recognising gender ideology as a super ideology. Given the time elapsed from the enactment of the Convention on Children's Rights, various theoreticians believe it is necessary to revise its provisions in order to better protect children including raising the age limit of childhood. Conflicting views, a clear outlook on the future and wellbeing of children as an aim are chances to redefine the world and children's rights, reinstating the dignity of the family and children.

Key words: child rights, rights to freedom of expression, children's rights to identity, child health rights, gender ideology. 